\title{
ظاهرة السحر والشعوذة مدارسة في المفهوم والأنواع والأهداف
}

\section{Shayuthi Abdul Manas}

Universiti Islam Sultan Sharif Ali (UNISSA) Brunei Darussalam

Email: shayuthy1551@gmail.com

\section{Ismail Abdullah}

Universiti Islam Sultan Sharif Ali (UNISSA) Brunei Darussalam

Email: ismailla1771@gmail.com

\section{Ahmed elMogtaba Bangga}

Universitas Islam Antarbangsa Malaysia

Email: elmogtaba@iium.edu.my

تناولت الدراسة عن السحر وملازماته من الثعوذة والعين والمس، وها،

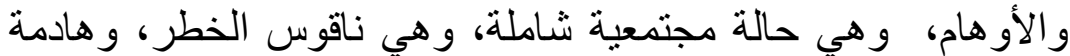

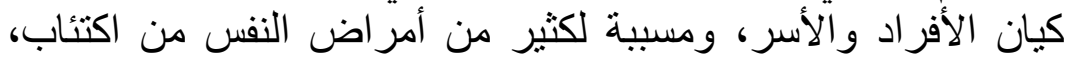

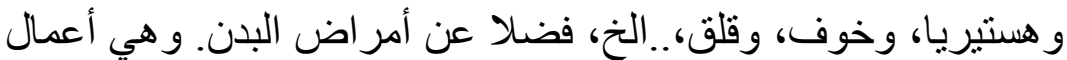

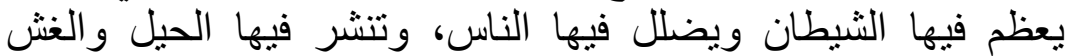

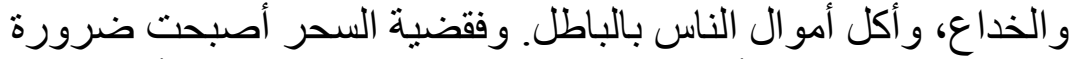

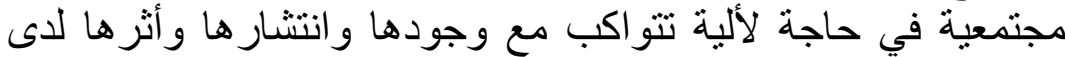

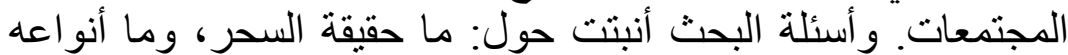

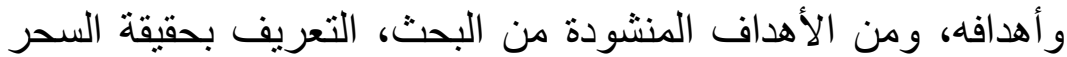

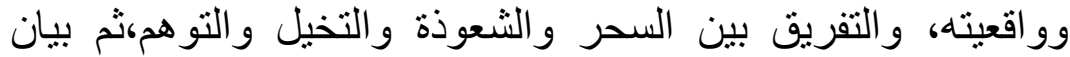
أنو اعه و أهدافه. ومن ثم النظر في نتائج الدر اسة و التوصئن ولنيات المستفادة. وحسب طبيعة الدراسة أن الباحثين سيعتمدون عل المنهان النهان الوصني و التحليلي في بيان الموضوع للخروج بأهم النتائج المهمة.

الكلمات المفتاحية: السحر، الثعوذة، مدرسة، المفهوم، الأنواع، الأهداف

Phenomenon of witchcraft and sorcery is schooled in the concept, genres and goals. The study dealt with the magic and its syndromes of sorcery, the eye, touch, and illusions. It is a comprehensive societal situation, it is an alarm for the danger, the destructive entity of individuals and families. It causes 
many mental diseases such as depression, hysteria, fear, anxiety, etc... As well as body diseases. These are acts in which Satan is glorified and the people are misguided. It spreads tricks, cheats and deceptions, and eats people's money falsely. The issue of witchcraft has become a societal necessity that needs to be kept pace with its existence, its spread and its impact on the societies. The research questions were based on: What is the reality of magic? What are its types and objectives? One of the objectives of the research is to introduce the truth and reality of magic, and to differentiate among the magic, sorcery, imagination and delusion. Then the statement of its types and objectives. Then the results of the study and the recommendations learned are considered. Depending on the nature of the study, researchers will rely on the descriptive and analytical approach in the topic statement to produce the most important results.

Keywords: Magic, Sorcery, Schooling, Concept, Genres, Goals.

\section{مقدمة}

أضحى السحر وملازماته من الثعوذة والعين والمس، و الأوهام،

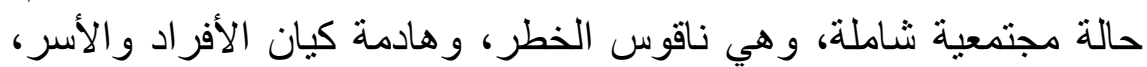

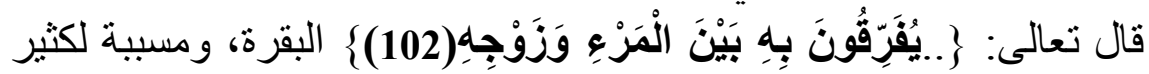

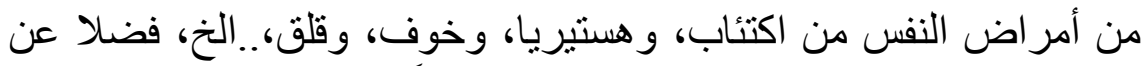

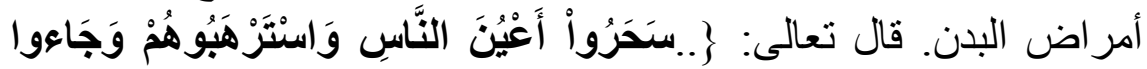

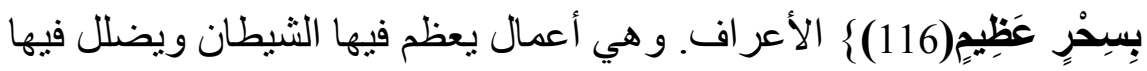

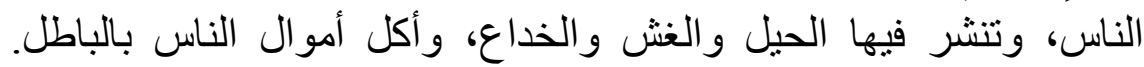

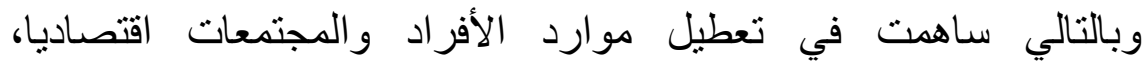

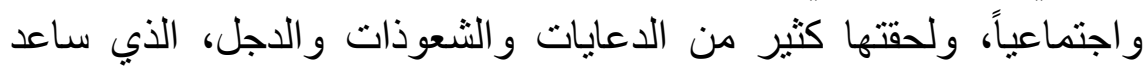

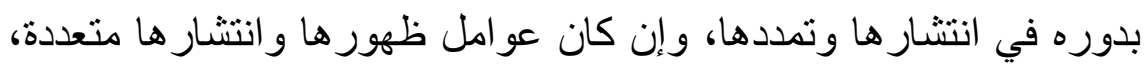

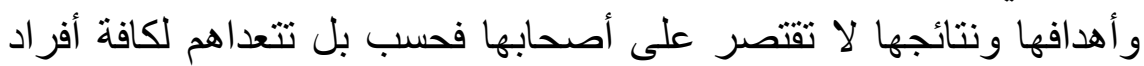

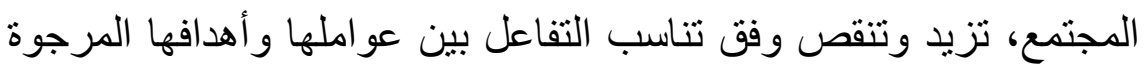
منها، بما يحتم وضع خطط محكمة في توصيف الحلول لتكون متو افقة مع 
ذات الأسباب والأهداف والنتائج المرجوة من السحر وملازماته، وتأتي

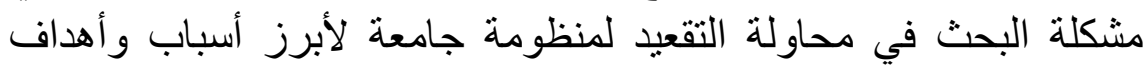
السحر، و التفريق بين السحر و التوهم، وبين السحر كو اقع و الشعوذة و والدجل ولئل

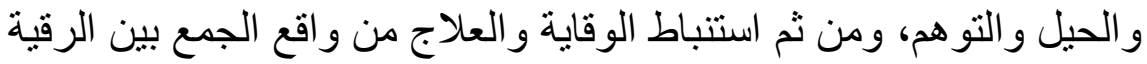

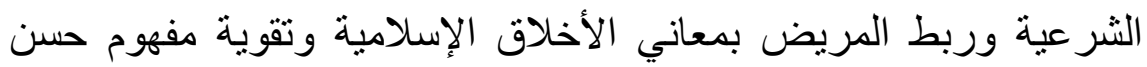

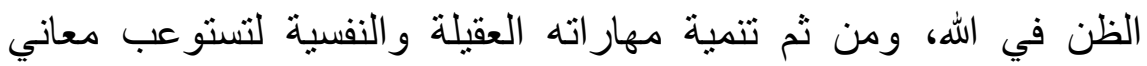

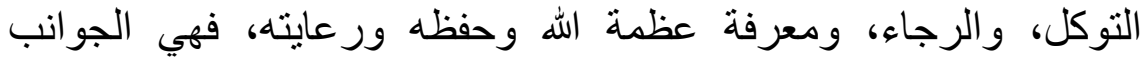
النفسية التي يسعى السحر لهدمها لادى المرضى ليتمكن من السيطرة عليهم،

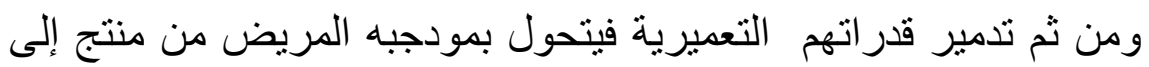

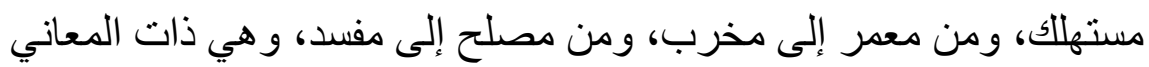

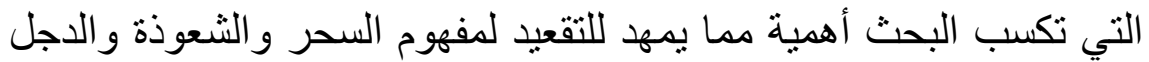
والخداع والحيل، ويبين أوجه التداخل والخصوصية لكل منهم، ويستنبط

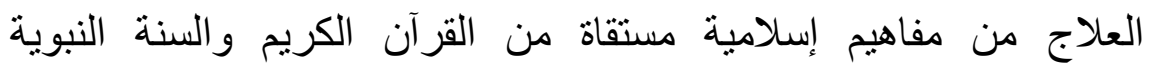

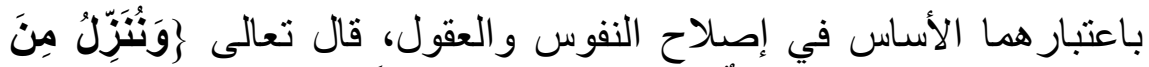

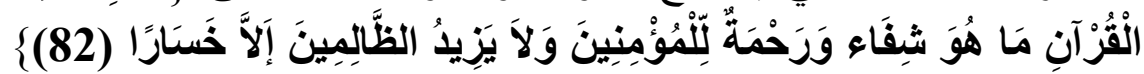

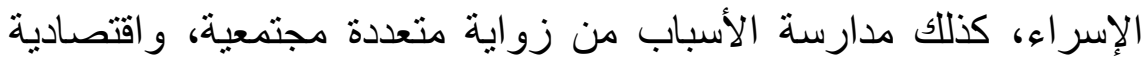

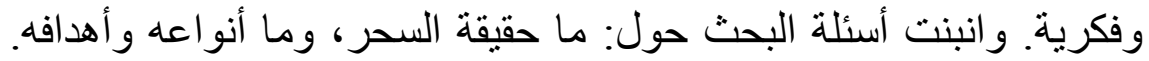

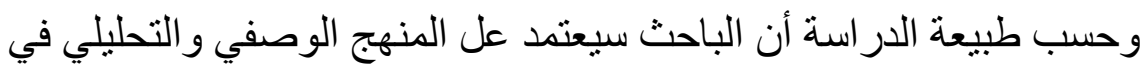
بيان الموضوع للخروج بأهم النتائج المهمة.

\section{المبحث الأول: مفهوم وواقعية السحر}

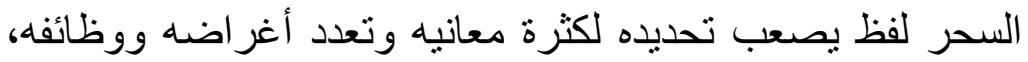

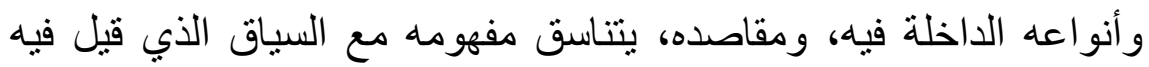

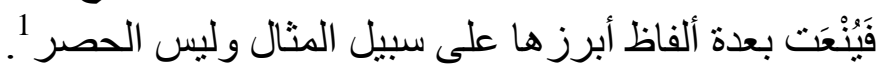

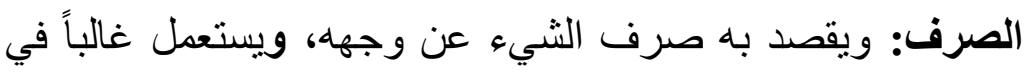
الخطابة والبيان، ويعني إظهار المقصود بأبلغ لفظٍ، وهو وهنه ونم عن ذكاء

1 انظر: المقال المنشور تحت عنوان: أثر السحر في الإضطرابات النفسية قراءة في ثناينا الحديث النبوي، بجلة مركز أبحاث الإيمان، الخرطوم السودان، 2004م. د.أحمد البحتبى بانقا، الجحامعة الإسلامية العالمية 
94 Rausyan Fikr, Vol. 17 No. 1 Januari 2021: 91 - 117.

ومهارة خطابية، يقلب بها قلوب السامعين من تصور إلى تصور مضاد².

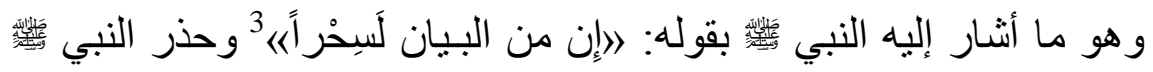
المسلمين من استعمال السحر اللفظي في غير موضعه، وهو الذي يقي يقلب

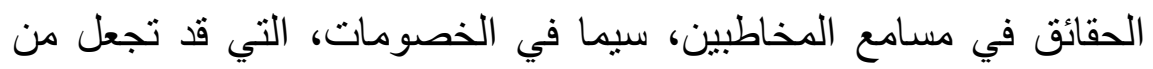
المظلوم ظالما، ومن الظالم مظلوما فقال بعضكم ألحن بحجته من بعض فمن قضيت له بحق أخيه شيئا بقوله فإنما أقطع لله قطعة من النار فلا يأخذهای). العقد: استوحي اسمها من الطريقة التي تدار بها، ويستلزم منه استحضار متعلق من متعلقات المسحور كثوب، أو شعر، ..الخ. وهو ما يغلب على ما يسمى بسحر الربط و التفريق، أو ما بسمى بالسحر الأسود، و هو عبارة عن عزائم وطلاسم تغير في الطباع، وتعرف أيضا (بالأخذة) يقال أُخذت، بمعنى غيرت صفاتها وطبائعها5، و هو ما أشار إليه القرآن

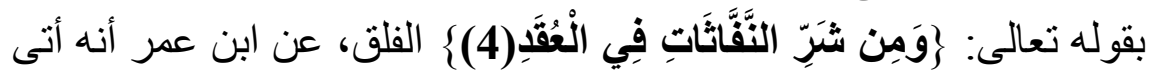

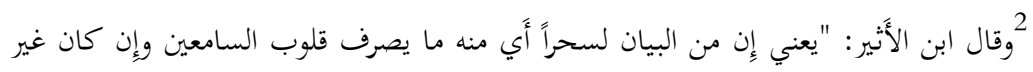

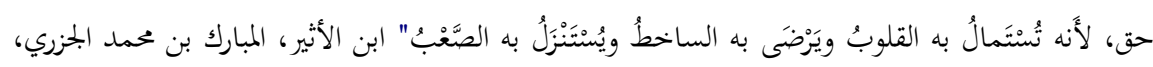

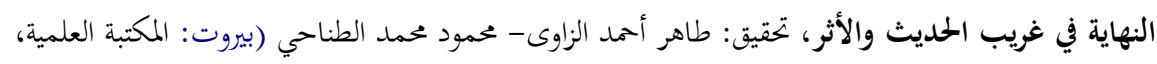

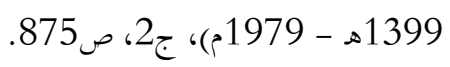

3 البخاري، محمد بن إسماعيل أبو عبد الله: الجامع الصحيح، تحقيق مصطفى ديب البغا (بيروت،

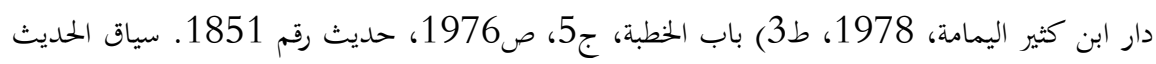

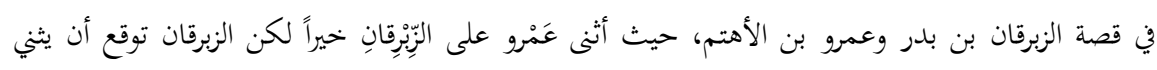

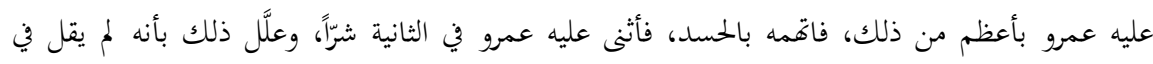

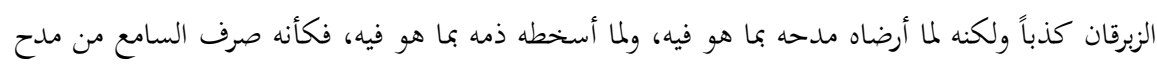

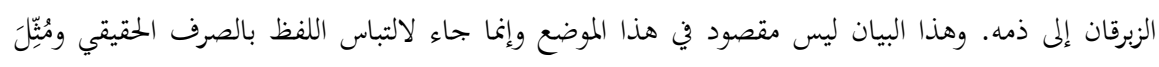
بالبيان لأثره في تحويل القول عن وجهه الحقيقي.

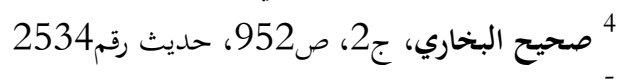

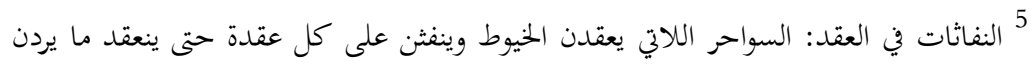

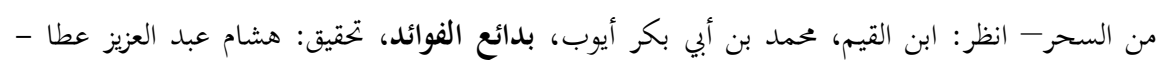

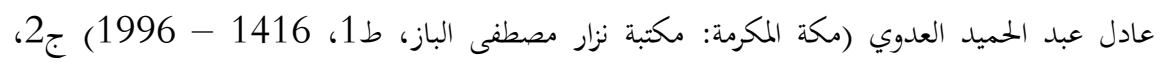


الطائف فإذا هو يرى التيوس تلب أوتتب على الغنم خافجة كثير ا، فقال

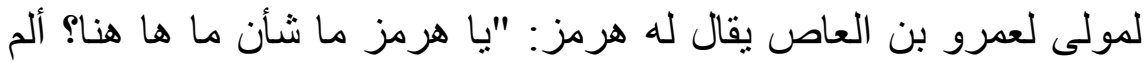

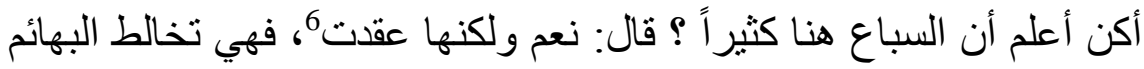

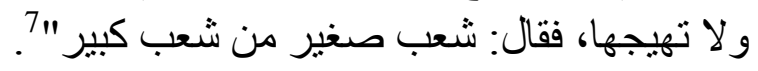

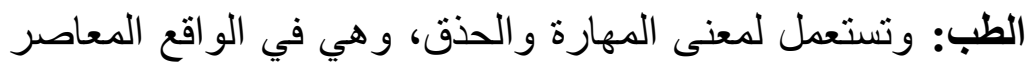

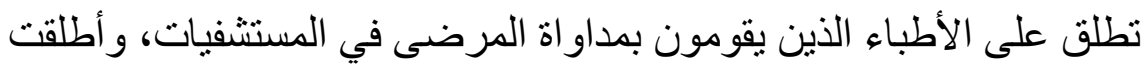

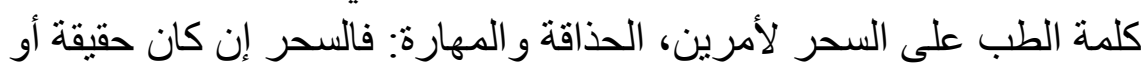

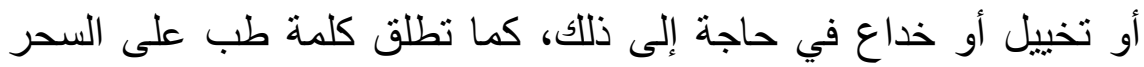

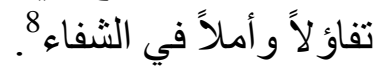

العِضَّة: وهو ما يختص بسحر التخيليل الذي يعتمد على المهارات

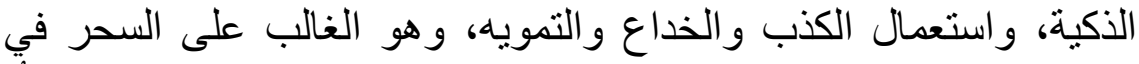

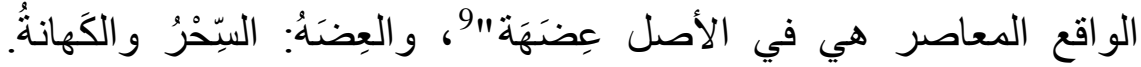

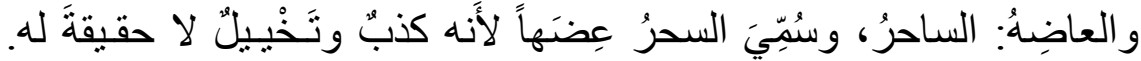

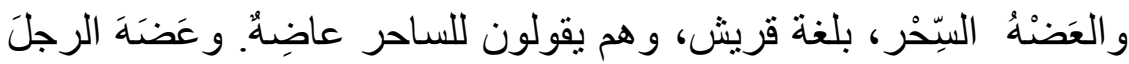

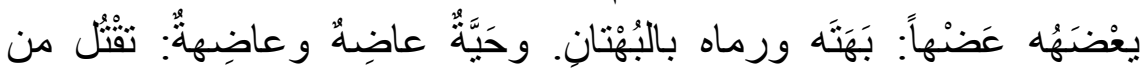

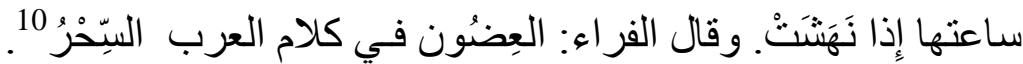

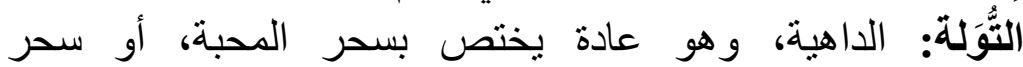

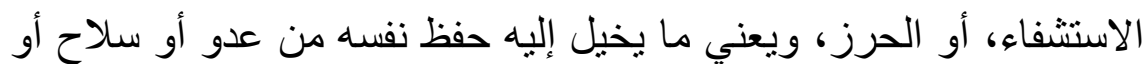

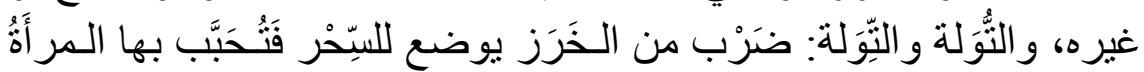

6 أخذت كما تؤنِّذ الروم الهوامَّ بالطلسم وشعب الأول بمعنى الإصلاح وشعب الثاني بمعنى

الإفساد أي كره ذلك لأنه نوع من السحر.

7

الزخشري، محمود بن عمر، الفائق في غريب، تحقيق: علي محمد البجاوي-محمد أبو الفضل إبراهيم (لبنان:

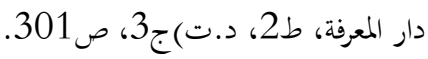

8 الفائق في غريب الحديث، ج)، 2، ص، ص353 ابن منظور، محمد بن مكرم بن منظور الأفريقي

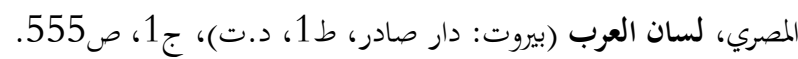

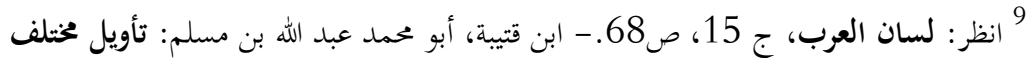

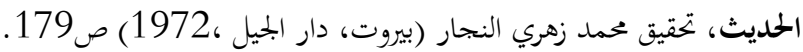

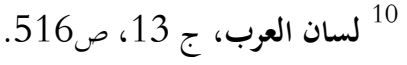


96 Rausyan Fikr, Vol. 17 No. 1 Januari 2021: 91 - 117.

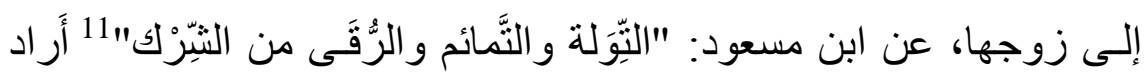

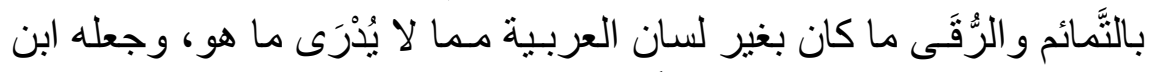

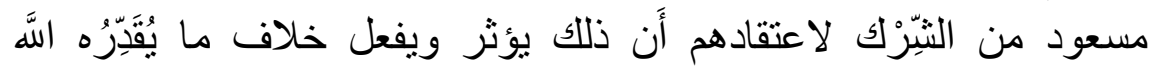
تعالى 12. و بالر غم من التباين في التعريف اللغوي للسحر، فإن جامعها هو:

$$
\text { صرف الثيء عن وجهه. }
$$

أما اصطلاحاً: يصعب الإجماع على تحديد مصطلح دقيق لمفهوم

السحر، نسبة لتشعبه، وشموليته، وتعدد آثاره و أنو اعه و أغر اضنه، وطرق

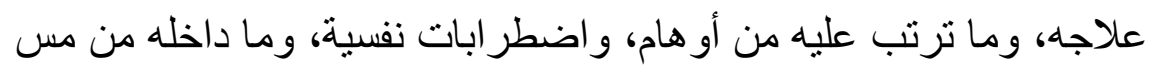

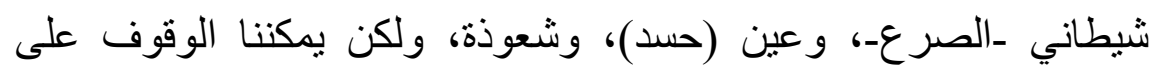
أقرب التعريفات لمصطلح السحر و التي منها:

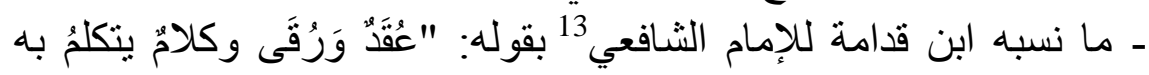
الساحر أو يكتبه أو يعمل شبئا، فيؤثر في بدن المسحور أو قلبه أو عقله من

11 وعن ابن أخت زينب امرأة عبد الله عن زينب رضي الله عنها قالت كانت عجوز تدخل علينا

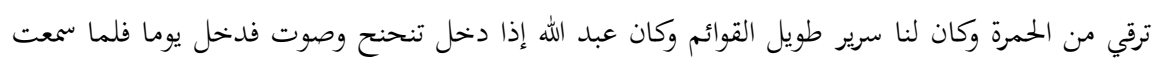

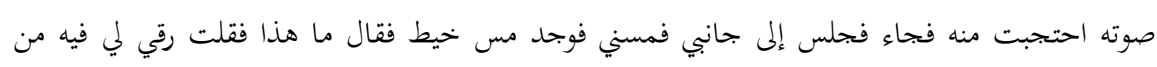

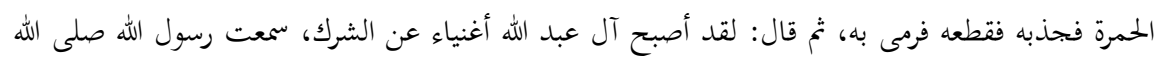

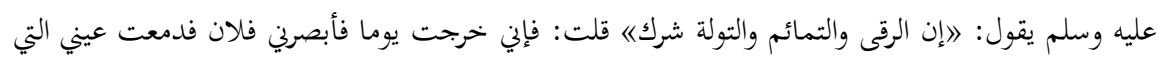

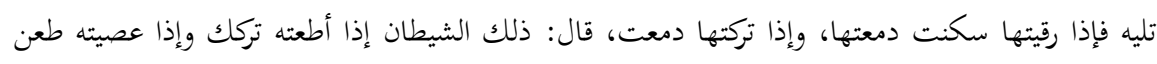

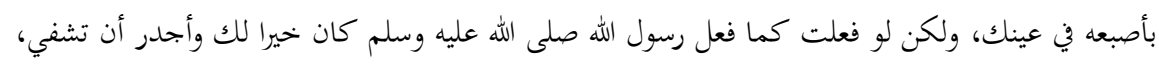

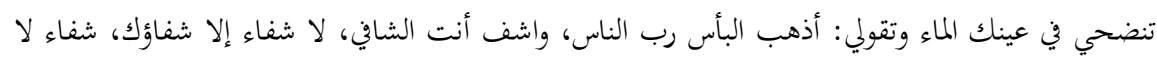

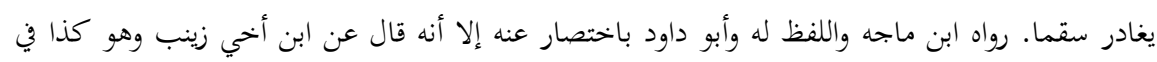

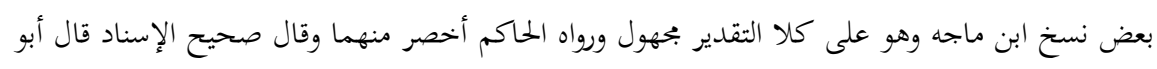

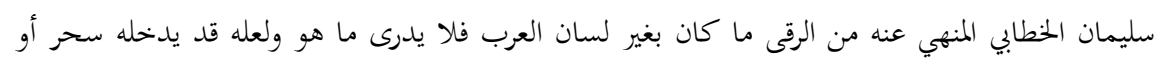

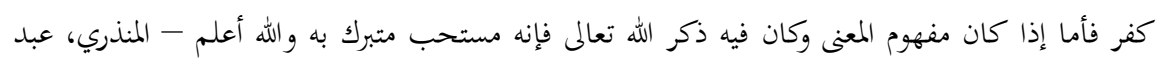

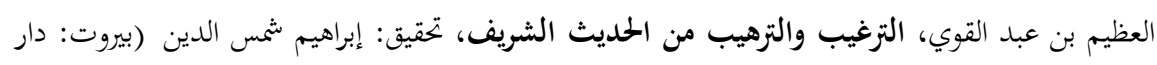

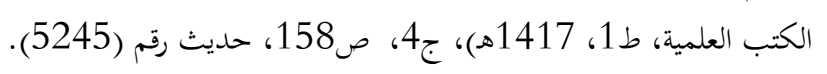

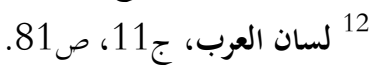

13

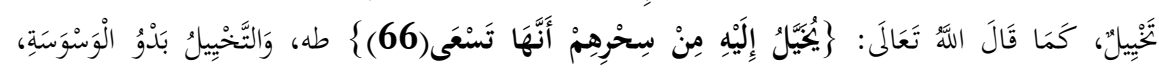




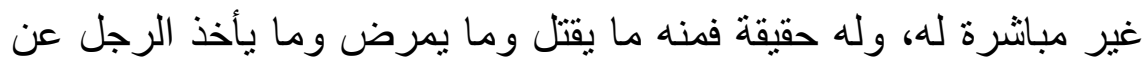

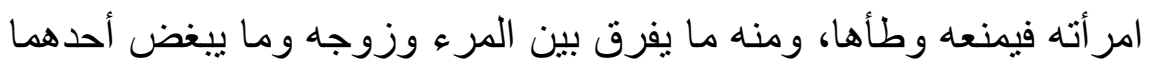

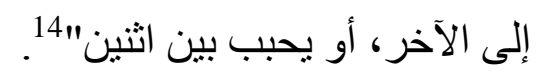

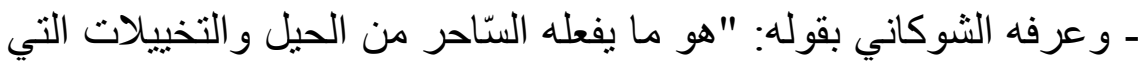

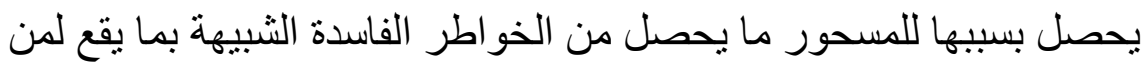
يرى السّر اب فيظنه ماء، وما يظنه راكب السفينة أو الدابة من أن الجبال تسبر "15.

- و عرفه صاحب كثف الظنون: "ما خفي سببه، وصعب استتباطه لأكثر

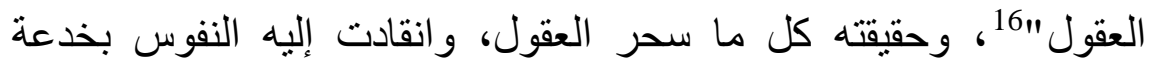

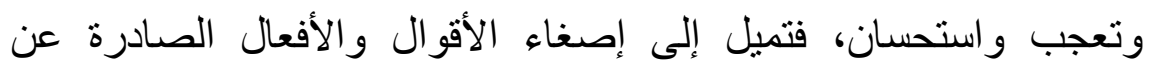

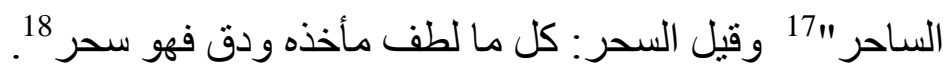

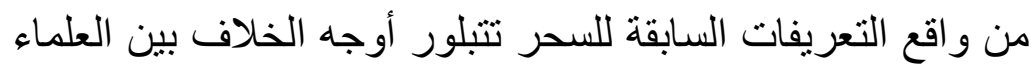

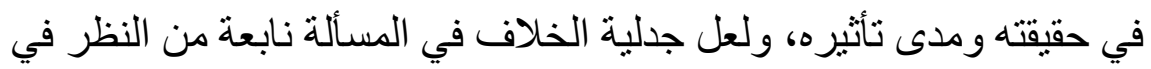

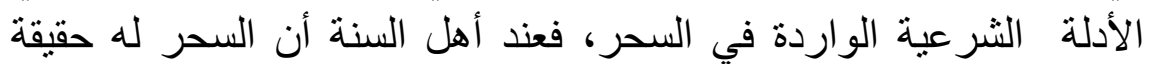

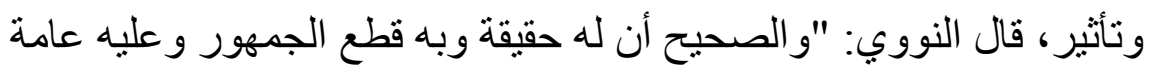

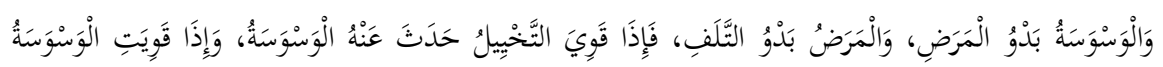

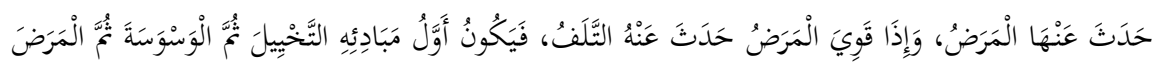

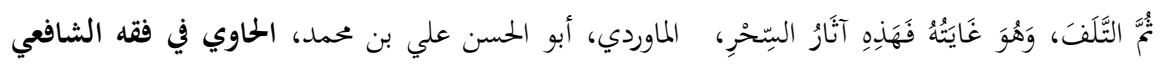

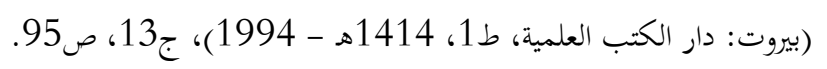

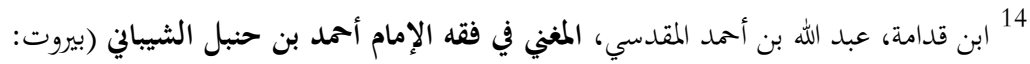

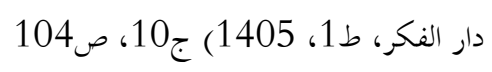

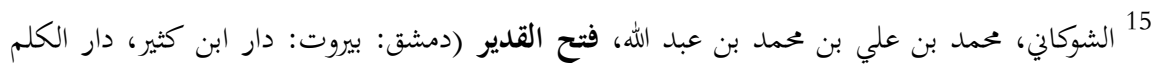

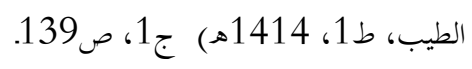

16 حاجي خلفية، مصطفى بن عبد الله، كشف الظنون في أسماء الكتب والفنون (بغداد: 1314

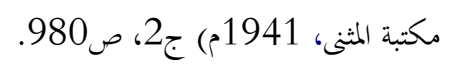

17 1القنوجي، صديق بن حسن: أبجد العلوم، تحقيق عبد الجبار زكار (بيروت، دار الكتب العلمية،

$$
\text { 1978م) ص 2، ج312. }
$$

18 1إسماعيل بن حماد الجوهري، الصحاح تاج اللغة وصحاح العربية، تحقيق: أممد عبد الغفور

$$
\text { عطار (بيروت: دار العلم للملايين، ط4، 1407هـ-1987م) }
$$


98 Rausyan Fikr, Vol. 17 No. 1 Januari 2021: 91 - 117.

العلماء ويدل عليه الكتاب والسنة الصحيحة المشهورة"19، يكون بالقول

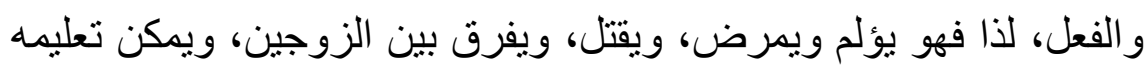

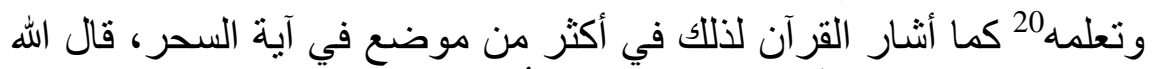

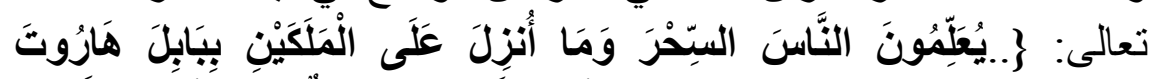

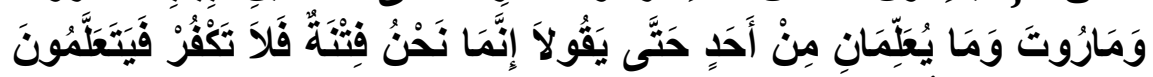

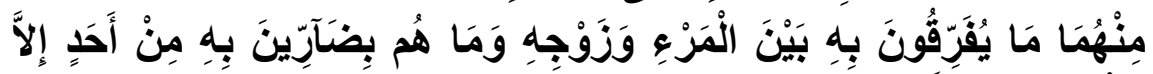

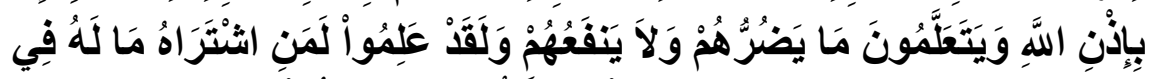

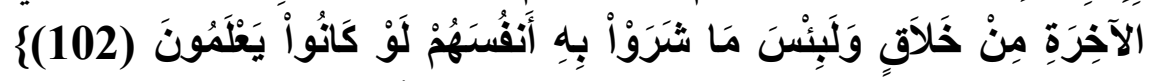

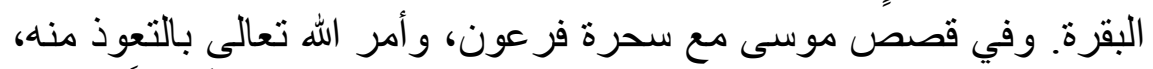

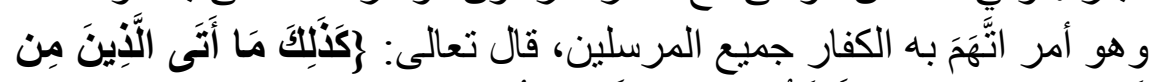

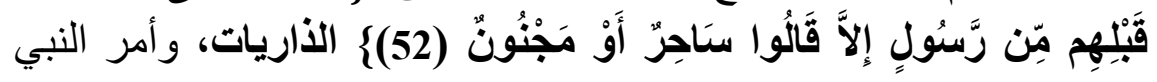

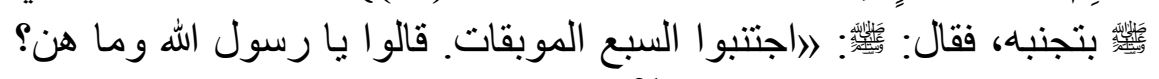

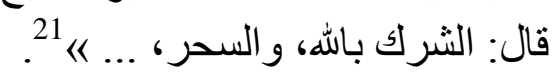

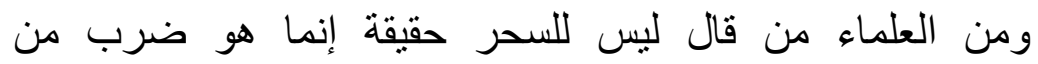

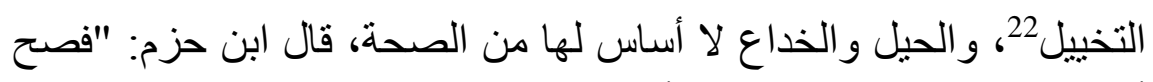

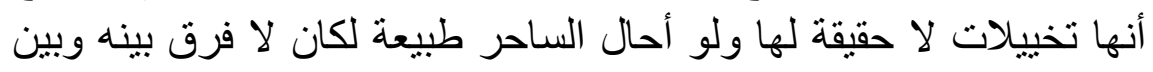

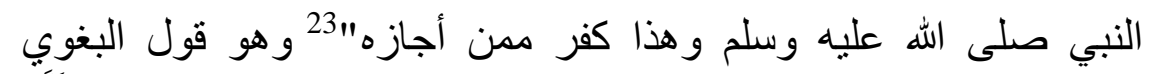

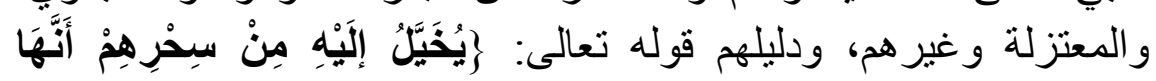
تََنْعَى(66)

\footnotetext{
19 1ابن حجر، أممد بن علي بن حجر العسقلاني، فتح الباري شرح صحيح البخاري، رقم كتبه

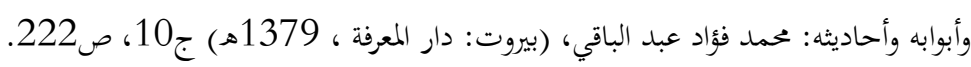

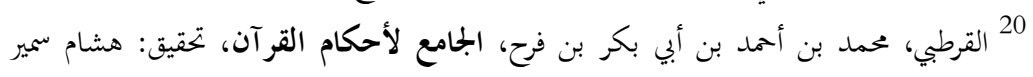

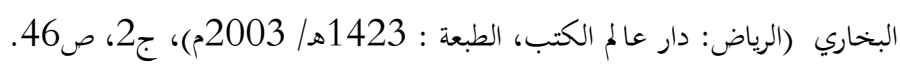

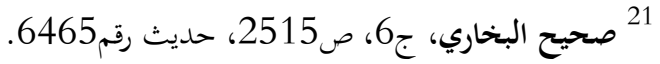

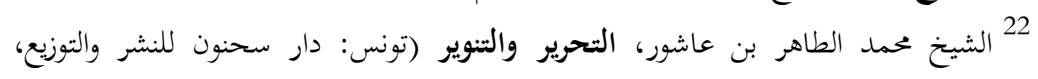

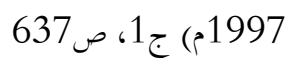

$$
\begin{aligned}
& 23 \text { 23 جن حزم، علي بن أممد بن سعيد الظاهري، الخلى، تحقيق: للحنة إحياء التراث العربي (بيروت: }
\end{aligned}
$$

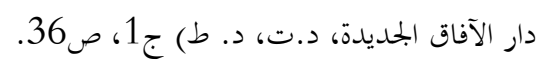


و الو اقع أن السحر حقيقة كان أو خيالاُ أثره ماثلا للعيان، بيدا أن كل أنواع السحر تتفق على أنه ليس بمقدور السحر قلب البه الأعيان، كما أن السحر

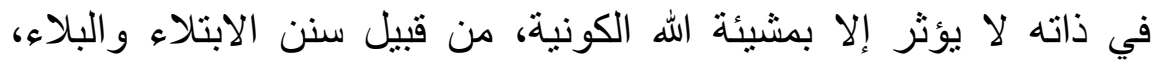

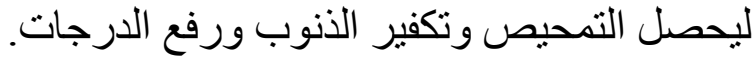

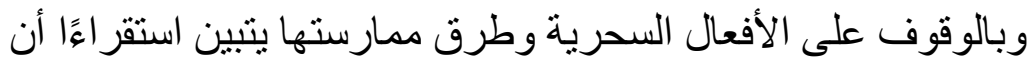

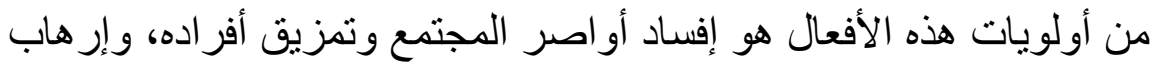

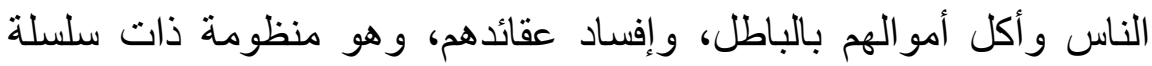

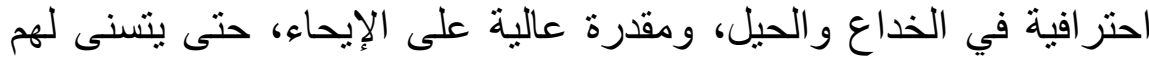

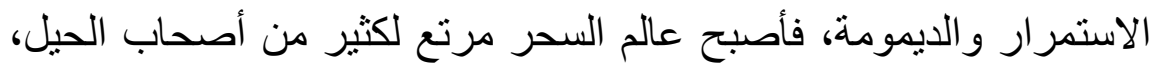

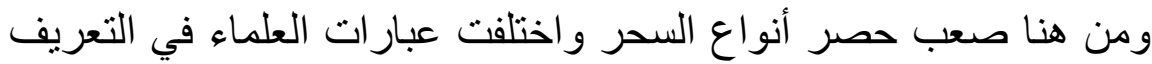

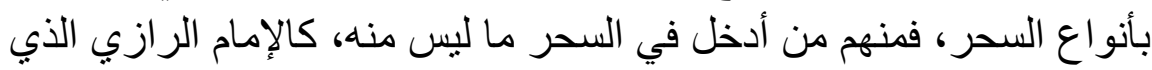

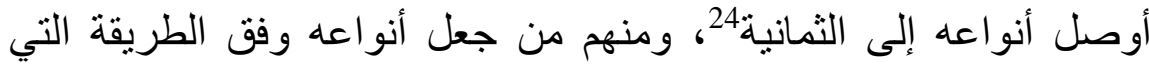

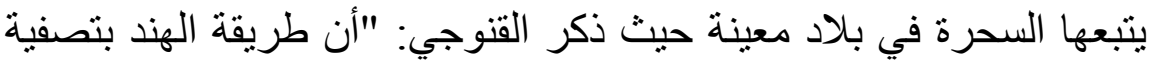

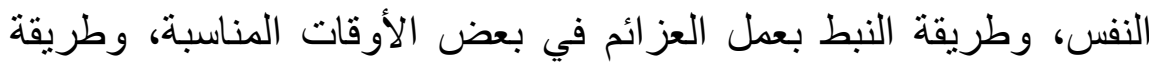

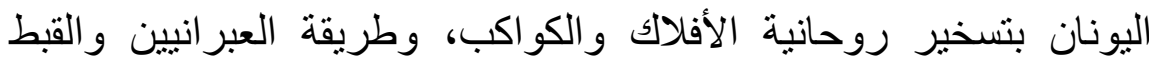

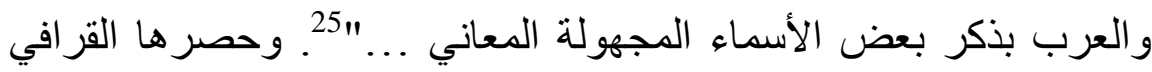

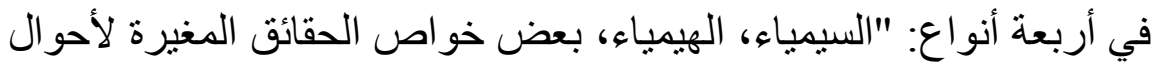

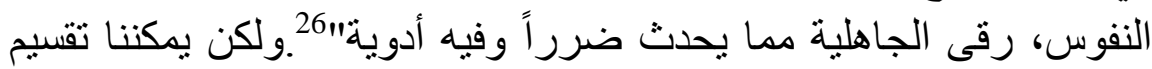

24 عدد الفخر الرازي ثمانية أنواع للسحر، أدخل أنواعا في الحقيقة لا تعتبر سحرا حقيقيا وربما

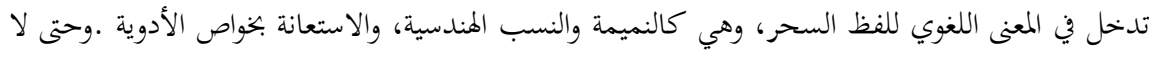

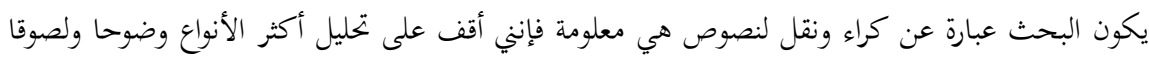

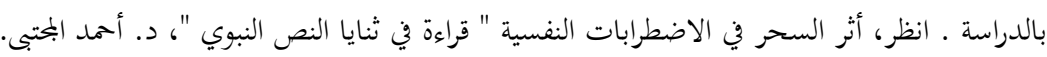

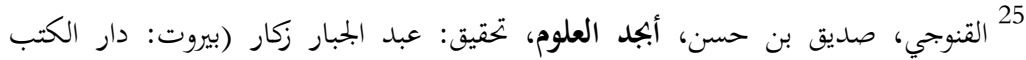

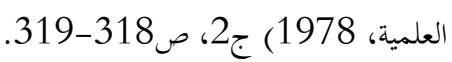

26 القرافي، أبو العباس أحمد بن إدريس الصنهاجي، الفروق أو أنوار البروق في أنواء الفروق،

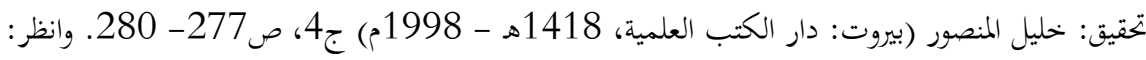

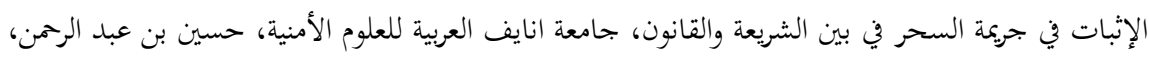

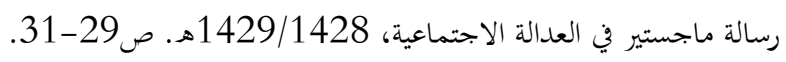


100 Rausyan Fikr, Vol. 17 No. 1 Januari 2021: 91 - 117.

أنواع السحر بالنظر في تنوع تصنيفاته عند العلماء إلى ثلاثة أنواع ويلحق بها النوع الر ابع وهو السحر المتوهم المبحث الثاني: أنواع السحر النوع الأول: ما ارتكزت حقيقته على تعاون بين السحرة والجن وهو ما توافرت فيه الثروط والأركان السحرية، وهي على سبيل

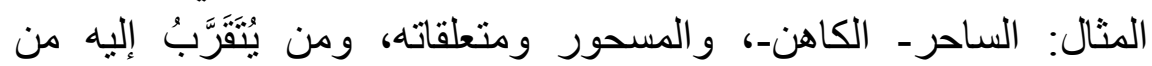
الثياطين والجن، وتصاحب هذا النوع عزائم، و أدوية وأبخرة، وطلاسم

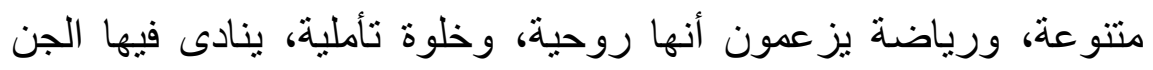
و الثياطين الذين يرمز لهم بأسماء اصطلاحية، وتأملات يزعمون فون أنها تسهم في التقرب من الجن وكسب وده، ويقصد بها التقرب إلى الثباطين، وهي أبرز أنو اع السحر التي توصل أصحابها إلى الكفر ، لما فيها من إدعاء الغيب وتسخير الثياطين والاعتقاد فيهم، وتعظيمهم، والإفساد في الأرض،

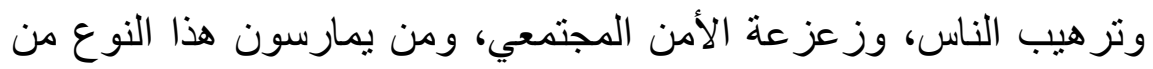
السحر صنفين من الناس أولهم السحرة المحترفون الذين تظهر على أيديهم

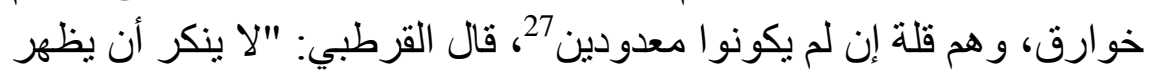
على يد الساحر خرق العادات مما لبس في مقدور البشر من مرض وض وتفريق

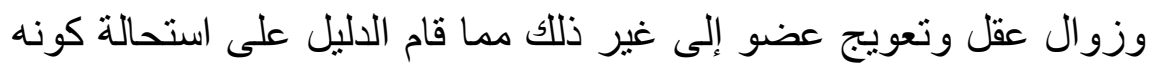

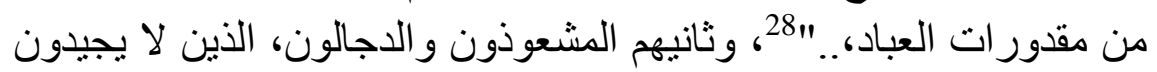
هذه الصنعة، و إنما هم هواة وجدوا ضالتهم في هذه الصنعة وفي الغالب تأثير هم على المسحورين نفسي قائم على الغش والخداع و الحيل والإيحاء، و هو الغالب على من يمارسون هذه الصنعة من الناس، لقلة المهرة في

\footnotetext{
27 إبراهيم كمال أدهم، السحر والسحرة من منظار القرآن والسنة (بيروت: دار البشئر

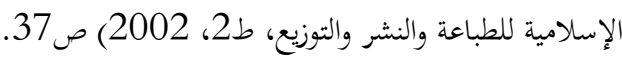

28 القرطب، محمد بن أحمد بن أبي بكر، الجحامع لأحكام القرآن، تحقيق: هشام سمير البخاري

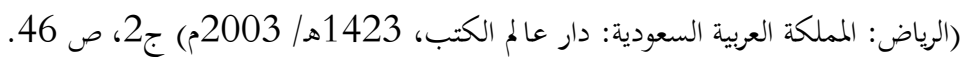


Shayuthi, Ismail, Ahmed, .... طاهرة السحر والثعوذة مدارسة

الأفعال السحرية، وهذا النوع من السحر أكثر ما يعاني منه الناس إن كان

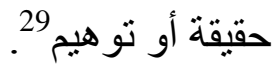

\section{النوع الثاني: سحر التخييل والترهيب}

وهو يعتمد بشكل أساس على تراكيب خصائص الأشياء مثل

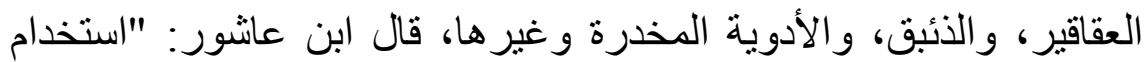

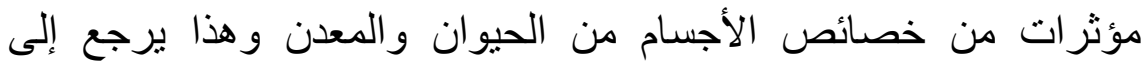

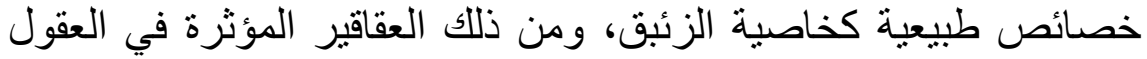

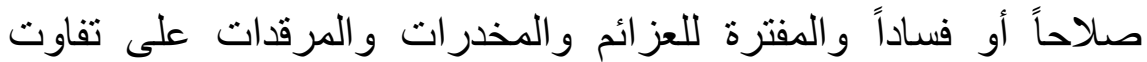

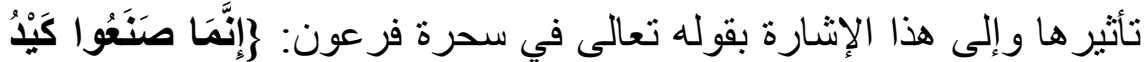

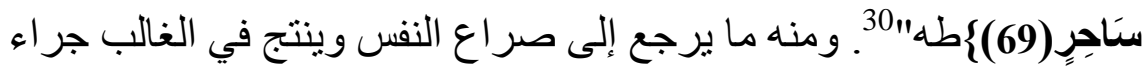

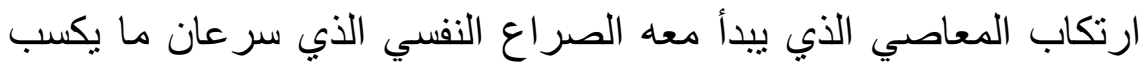
النفس إيحاء وقابلية لتصديق الثائعات، والاستسلام للأوهام التي لا لا حقيقة

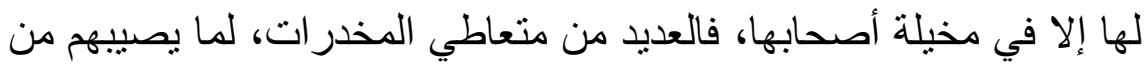

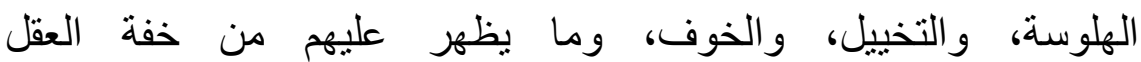

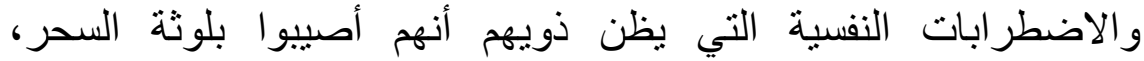

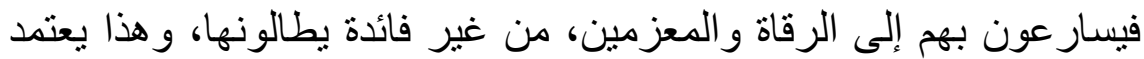

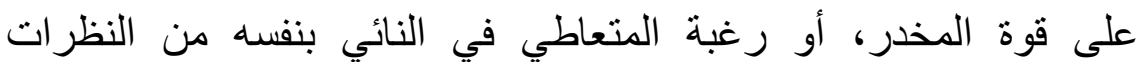

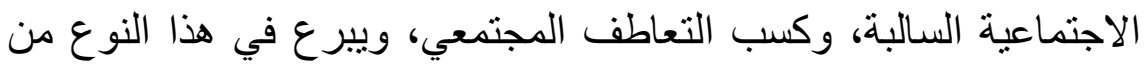

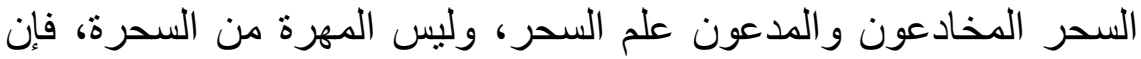

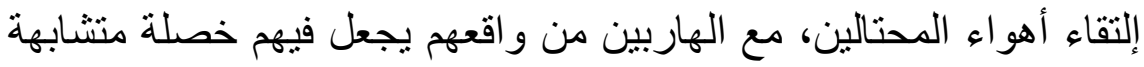

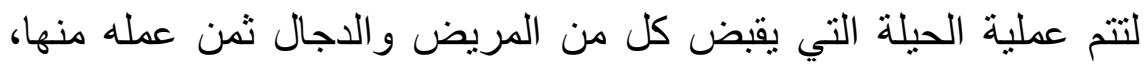

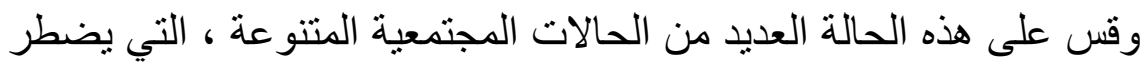

29 الكتب المتخصصة في السحر، مليئة هذا الفن وما يقوم عليه من مناداة بأسماء الجن،

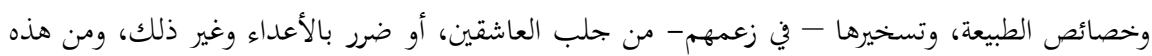

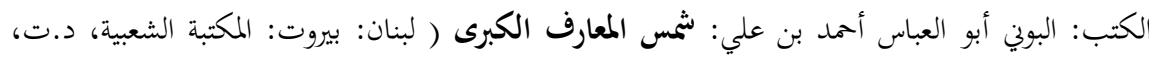

(b.)

30 ابن عاشور، محمد الطاهر التونسي، التحرير والتنوير المعروف بتفسير ابن عاشور (لبنان:

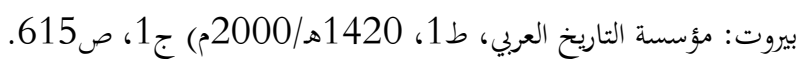


102 Rausyan Fikr, Vol. 17 No. 1 Januari 2021: 91 - 117.

إليها من يخبئون فثلهم وعدم استعدادهم لمواجهة الحقائق بالدجالين و المشعوذين، فقد تدعي زوجة المرض لإخفاء علة أو الوصول لهدف لا تستطيع الوصول إلبه بمصارحة الزوج، او كسب التعاطف معها بادعاء المرض، ونسبة للقبول المجتمعي في المشعوذين و الدجالين فتلجأ إلبهم حتى تكتمل الصورة التي لا بعرف حقيقتها من البشر غير صاحبتها والمحتال.

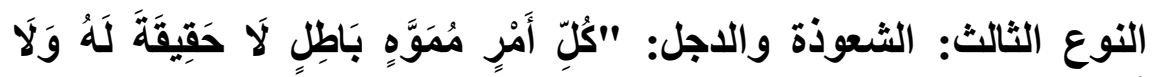
31 "تَبَاتَنَ

و هو يعتمد على خفة البد، وسر عة البداهة، و هو في غالبه كذب بحت

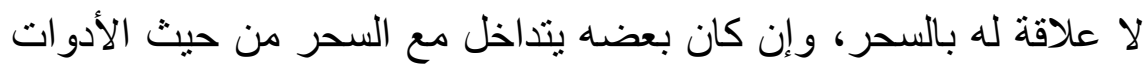
المستخدمة والطلاسم و الرسومات، التي لها علاقة بعلم الأفلاك و علم الحرف، و أسماء الجن، و غير ذللك..الخ. ولعل ما ذكره د. سعيد عبدلي في

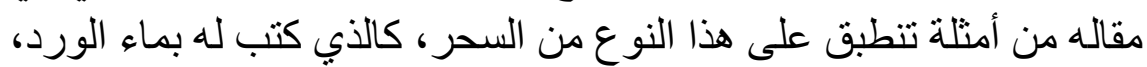

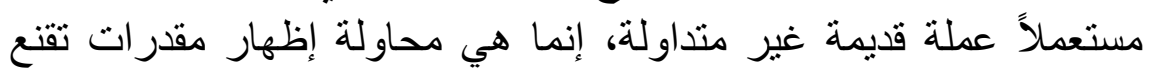

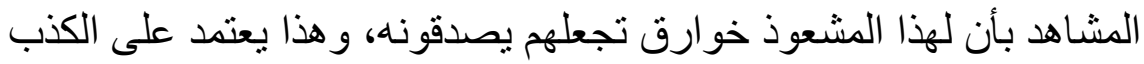
و الخداع، فالكتابة موجودة في حقيقتها و السبب في عدم ظهور ها كتابتها بماء الورد وليس بفعل السحر كما يدعي المشعوذ-، و الذي ساعد على ظهور ها وهودي

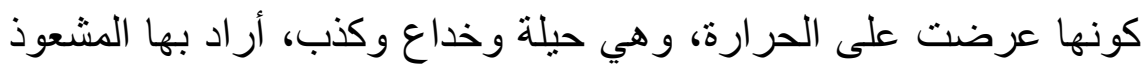
تحقيق غاية مادية، أو تكوين هالة مجتمعية، وتكثر هذه الأصناف من ون ونه الثعوذة وتتنوع لجاهزية المجتمع لتصديق مثل هذه الخرافات، التي ساهم

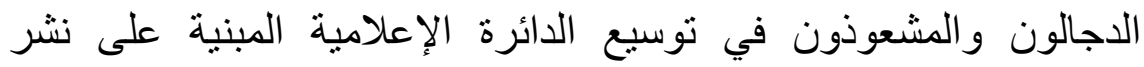
خوارقهم، وتر هيب الناس، حيث يعتمدون منظومة شبكية بالتعاون مع كثير

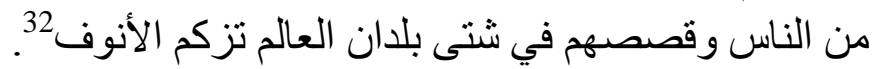

31 الجصاص، أحمد بن علي أبو بكر الرازي، أحكام القرآن، تحقيق: عبد السلام محمد علي

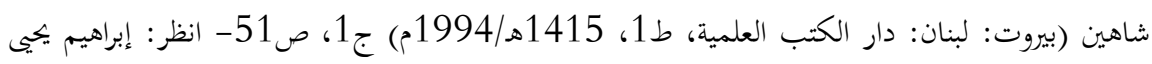

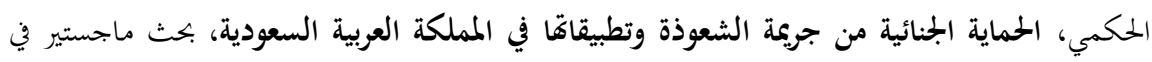

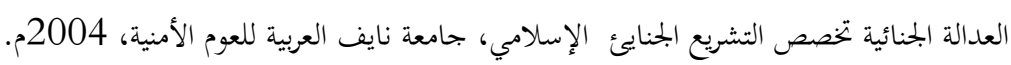

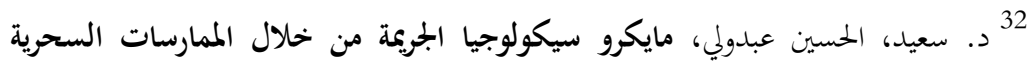

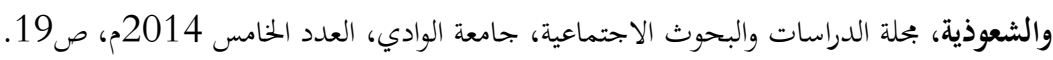




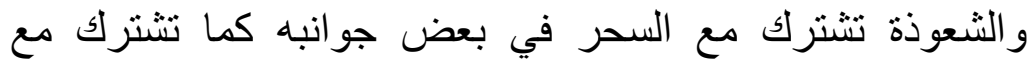
التخييل في جوانب أخرى فهي نوع من السحر متولد من النوعين النين الأولين

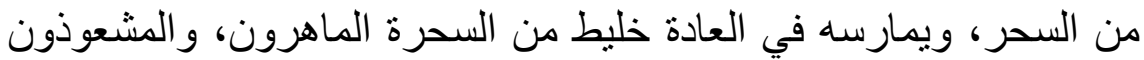

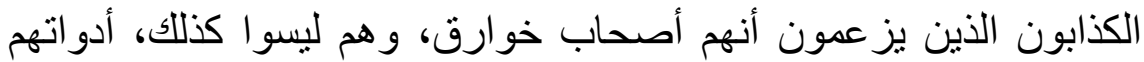

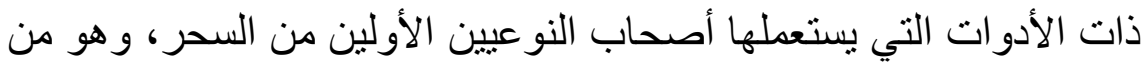

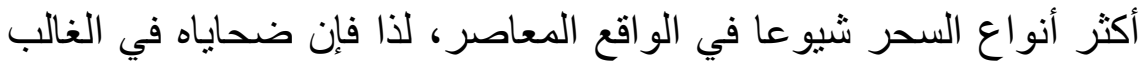

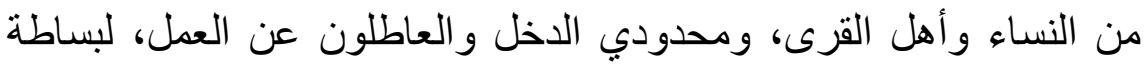

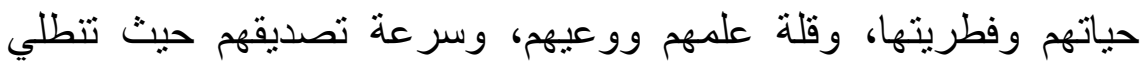

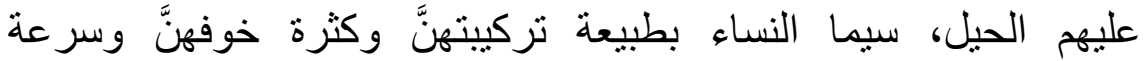

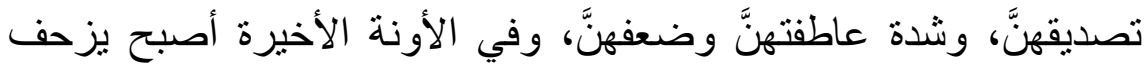
شره على شريحة من أصحاب المناصب، و المتعلمين، ربما لانتشاره وقوة

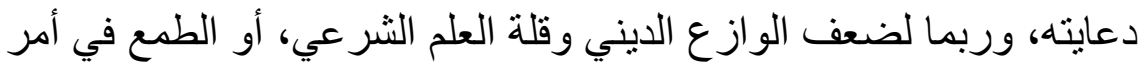

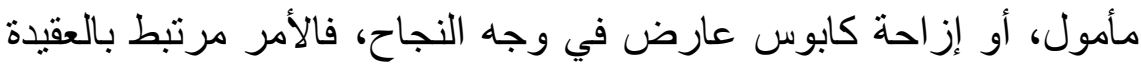

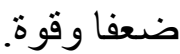

\section{النوع الرابع: السحر المتوهم}

التوهم من الوهم و هو مصطلح تزدحم فيه المعاني وتترجم مقاصده

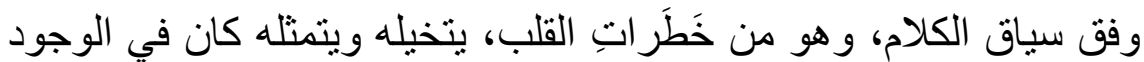

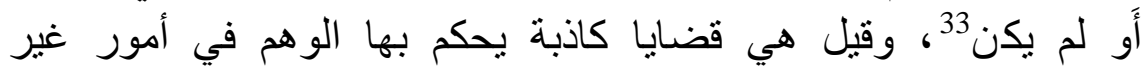

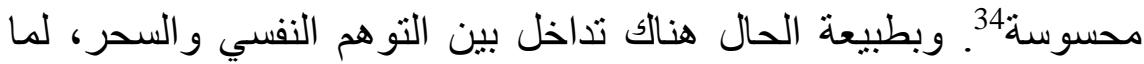

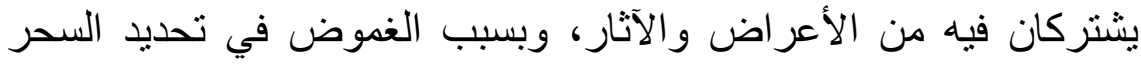

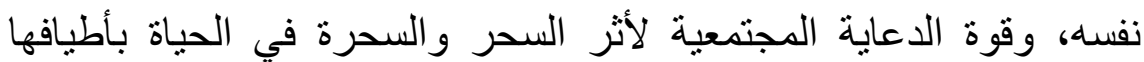
مجتمعة، و الهروب من الواقع الكئيب لبعض الأشخاص الثرة الذين اقتنعوا بتمثيل

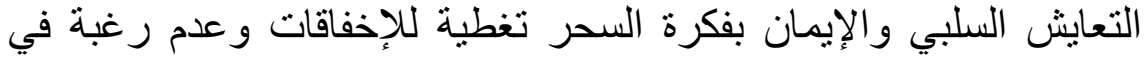
مو اجهة التحديات، فضلا عن الجهل بالسحر ومفهومه لدى الناس، و وانتشار$$
\text { 333 لسان العرب، ج12، ص643. }
$$

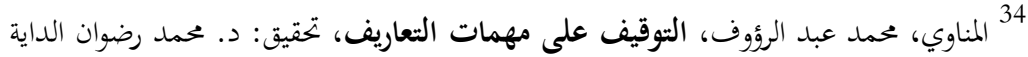

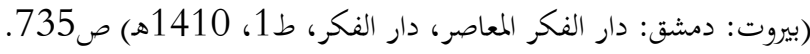


104 Rausyan Fikr, Vol. 17 No. 1 Januari 2021: 91 - 117.

المخدر ات بين الثباب وتماثل أعر اضها بأعر اض السحر و الثعوذة، هذه مجموعة من العوامل التي جعلت من التداخل بين السحر والوهم، وجعلت من توهم السحر قضية فاقت في حقيقتها السحر بحد ذاته، حيث تشتد حالة التداخل وتخف عند المو هومين وفقاً للكثير من الأسباب الداخلية و المحيطة بكيان الثخصية نفسها، فكثير من المرضى واعين ومدركين للجلسات العلاجية وما بعتريها من استحضار واستتطاق على لسان الجان كما يز عمون، وفي أغلب الأحيان هي تعابير عن مكنونات ضاغطة وفي حاجة للتنفيس، ومن أسهل طرق التنفيس اتهام المريض نفسه بأنها فيله مسحور، أو أصبب بالعين، وهي هروب من واقع محبطُ، أو خوف من الفشل في

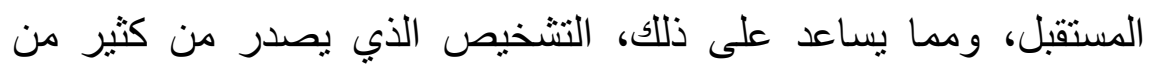

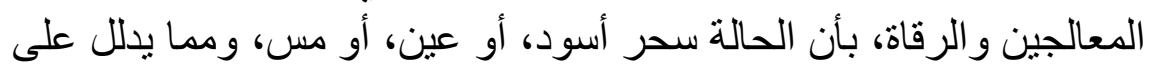

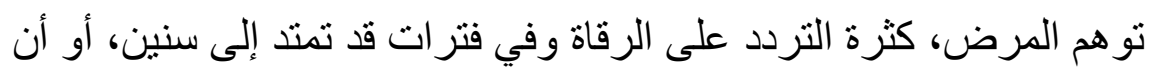

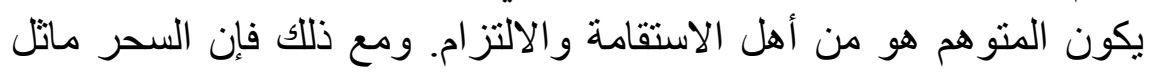
و هو حقيقة ومؤثر، ولكن بفضل الله تعالى الذي جعل عميلة نجاح السحر

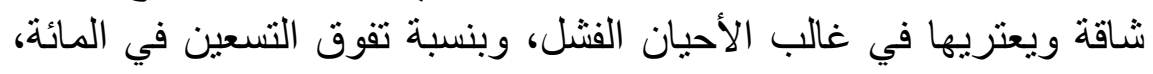
مدا يعني أن أغلب ما يدور في المجتمعات من قضايا السحر ومتعلقاته، إنما هي أوهام، ساعد على ظهور ها عواملة عديدة، بداءً بالمتو هم نفسها،

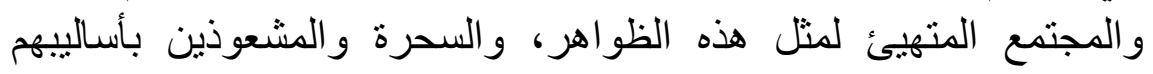
المختلفة و التي أسـاسها الحيل و الخداع و الكذب.

\section{التفريق بين الوهم والسحر:}

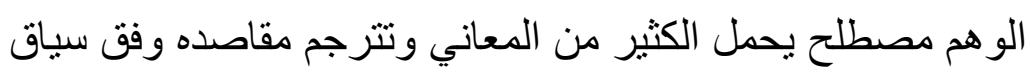

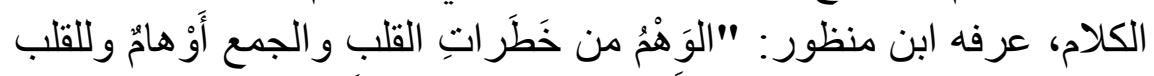

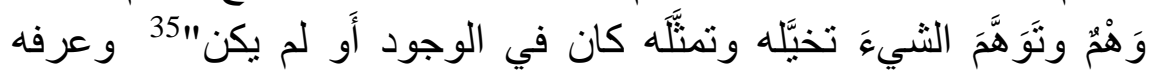
المناوي: "الو هميات قضايا كاذبة بحكم بها الوهم في أمور غير محسوسه

35 ابن منظور، محمد بن مكرم الأفريقي، لسان العرب (بيروت: دار صادر، ط1، د.ت)، 
كالحكم بأن وراء العالم فضاء لا يتناهى والقياس المركب منها يسمى هنالك تداخل بين التوهم النفسي والسحر، لما يشتركان فيه من الأعر اض والآثار، وبسبب الغموض في تحديد السحر نفسها، وقوة الدعاية

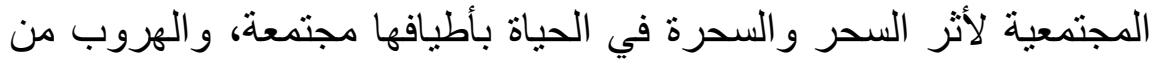
الو اقع الكئيب لبعض الأشخاص الذين اقتنعو ا بتمثيل التعايش السلبي و الإيمان بفكرة السحر تغطية للإخفاقات و عدم رغبة في مو اجهة التحديات، فضلا عن الإن التحني الجهل بالسحر ومفهومه لدى الناس، وانتشار المخدرات بين الثباب وتماتلل فئل فئل

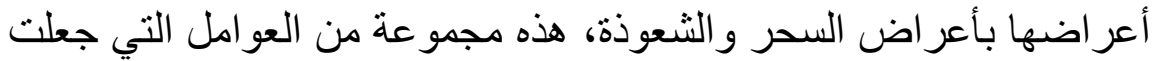

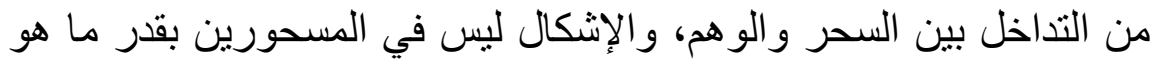

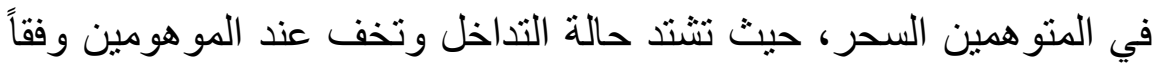

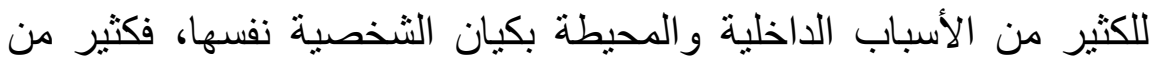

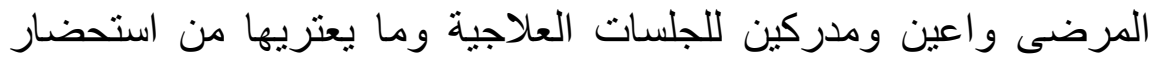

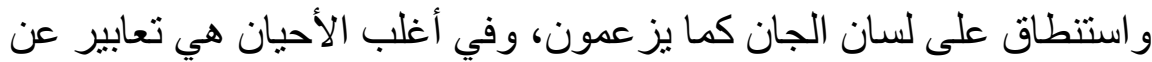

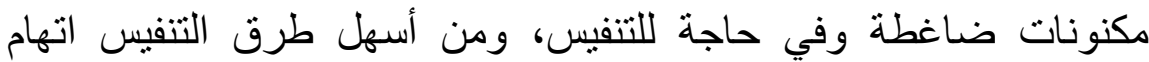

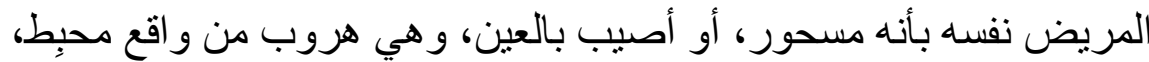

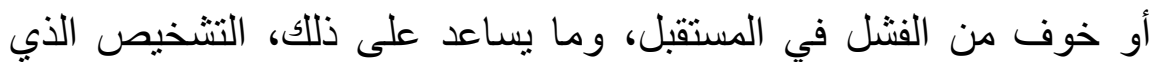

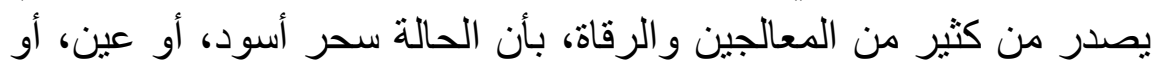

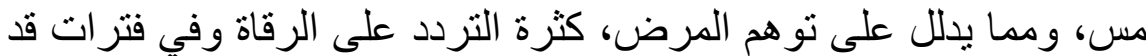

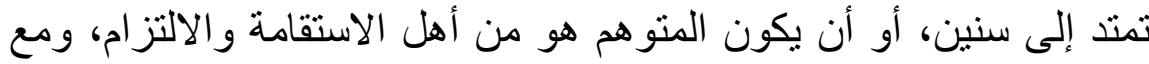

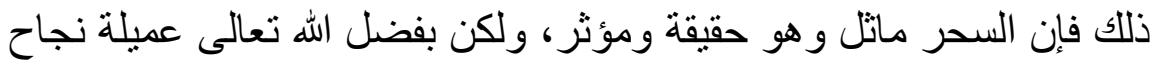

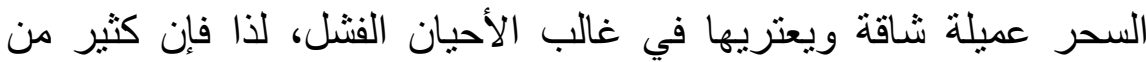

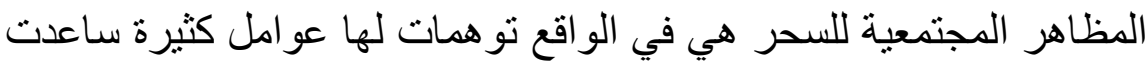

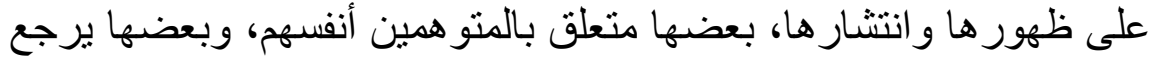

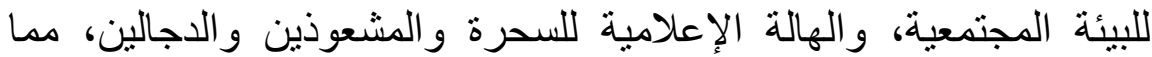
ساعد على خلط المفاهيم بين التو هم و السحر.

36 المناوي، حممد عبد الرؤوف، التوقيف على مهمات التعاريف، تحقيق : د. حممد رضوان الداية

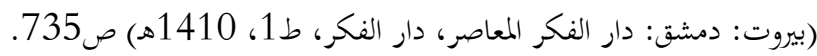


106 Rausyan Fikr, Vol. 17 No. 1 Januari 2021: 91 - 117.

\section{المبحث الثالث: الأهداف المجتمعية للسحر}

تختلف أهداف السحر باختلاف الأسباب و الدو افع، لذا لا يمكن حصر

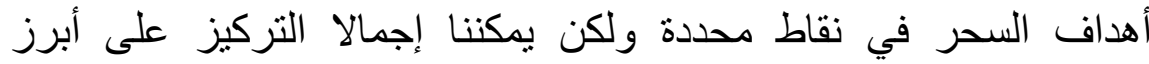

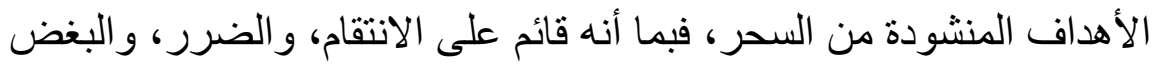

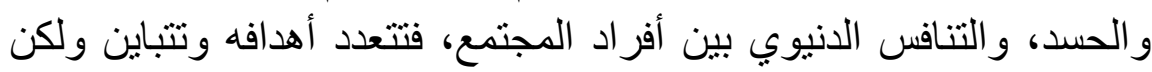

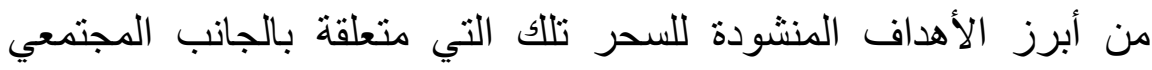
ومنها:

\section{1 - إحداث القتنة الزوجية}

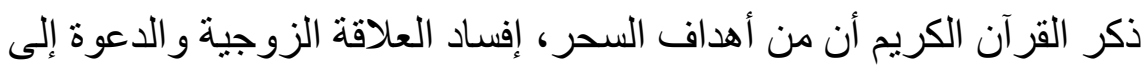

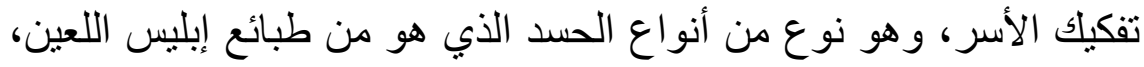

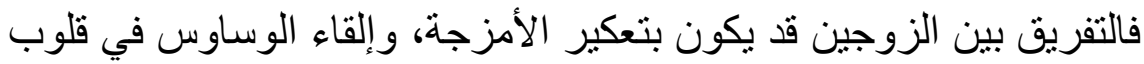

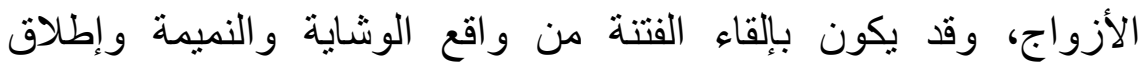

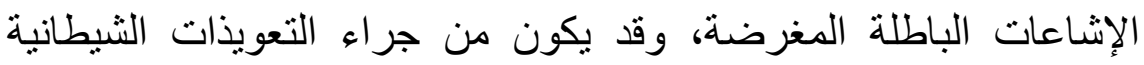

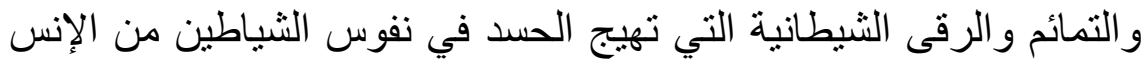

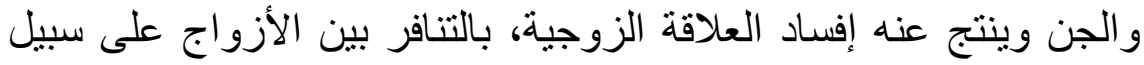

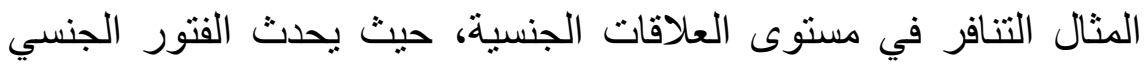

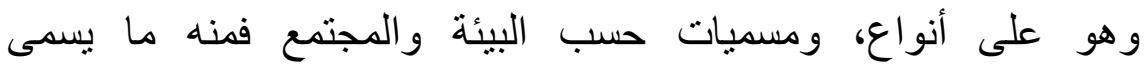

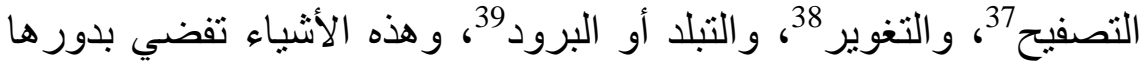

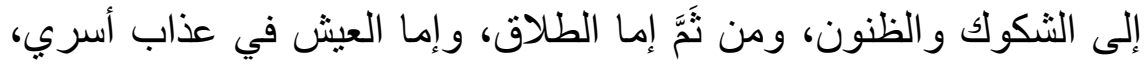

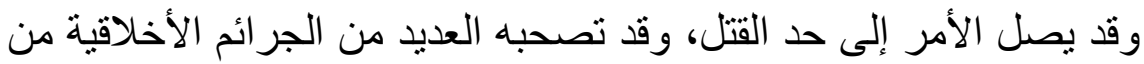

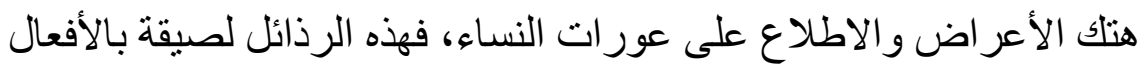

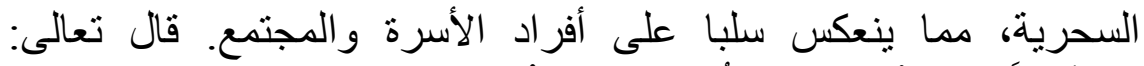

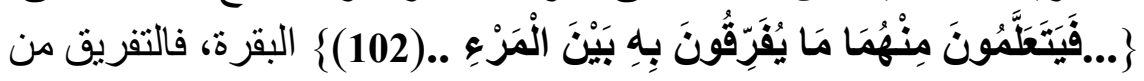

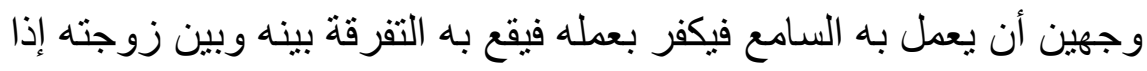$$
37 \text { نوع من سحر الربط لا يستطيع الرجل فيه من معاشرة الزوجة. }
$$

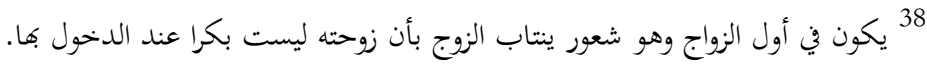$$
39 \text { يحصل للرجل والمرأة على حد سواء حيث تضعف الجلاذبية الحيمية في الجماع فيصيب المرأة }
$$$$
\text { والرجل برود جنسي قد يسبب فتور ووسوسة تفضي للطلاق. }
$$ 
كانت مسلمة بالردة، و الثاني أن يسعى بينهما بالنميمة و الوشاية و البلاغات

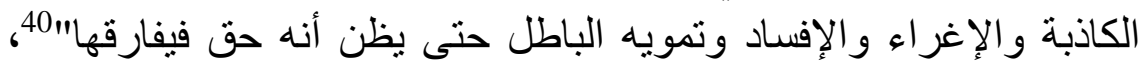

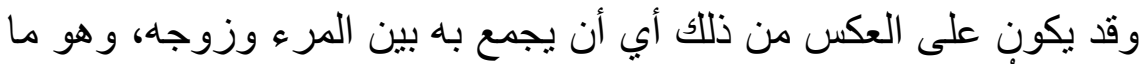

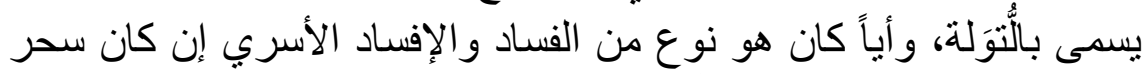

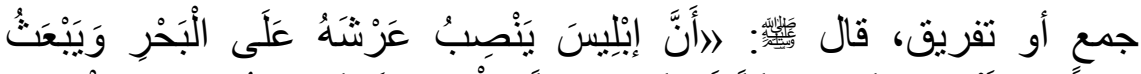

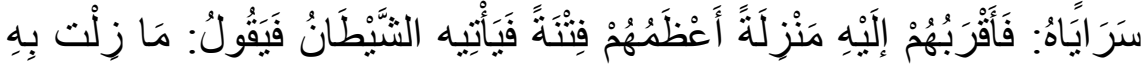

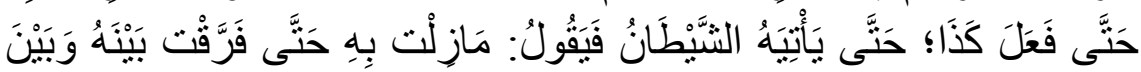

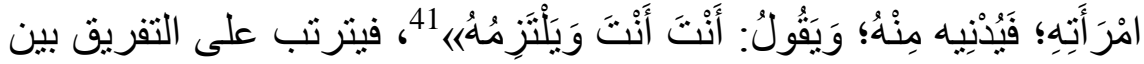

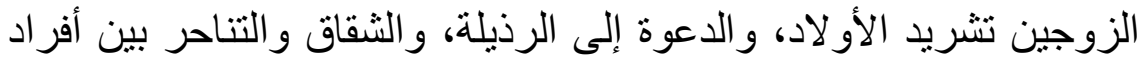

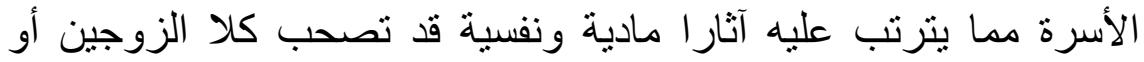

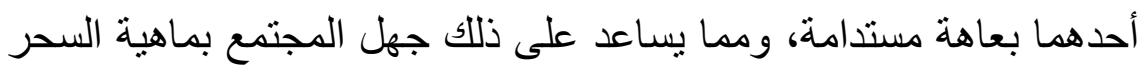

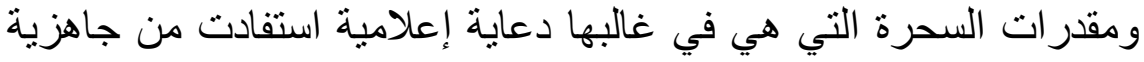

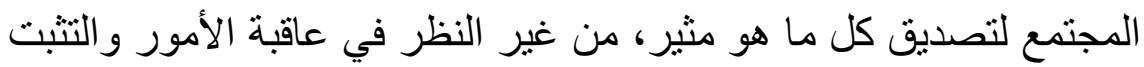

السحر هو غاية من غايات الكفر والعمل الثيطاني، والضلال المجتمعي،

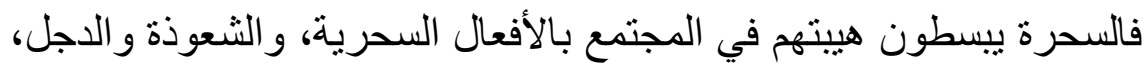

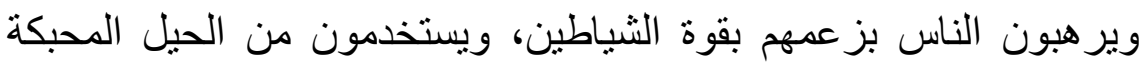

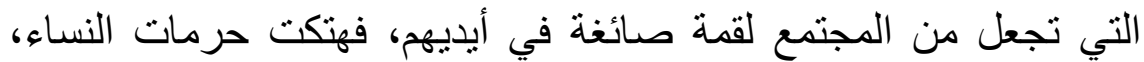

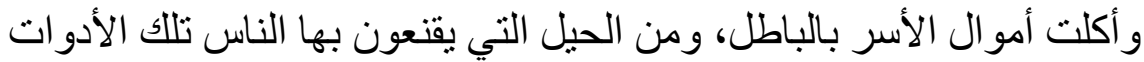

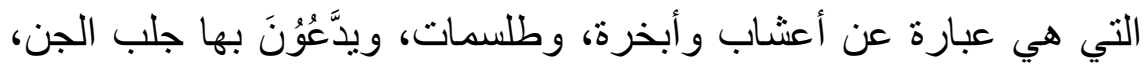

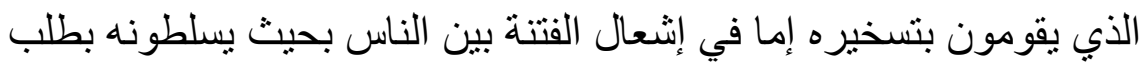

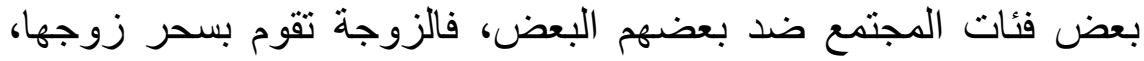

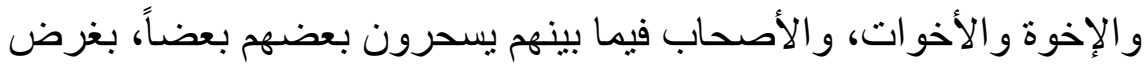

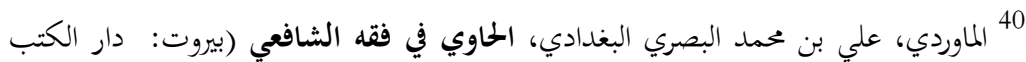

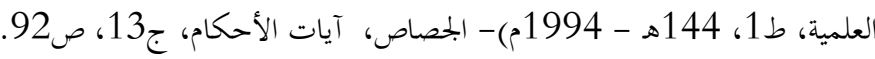

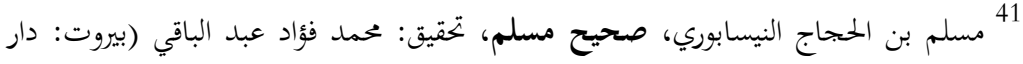$$
\text { إحياء التراث العربي، د.ت، د.ط) ج4، ص2167. }
$$ 
108 Rausyan Fikr, Vol. 17 No. 1 Januari 2021: 91 - 117.

الميراث أو التفاوت الطبقي في المال أو الجاه، أو بغرض الفوز الفوز بزوج

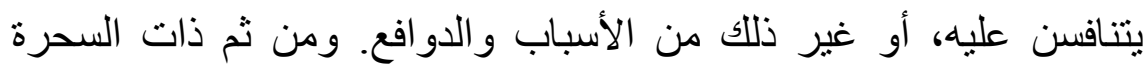

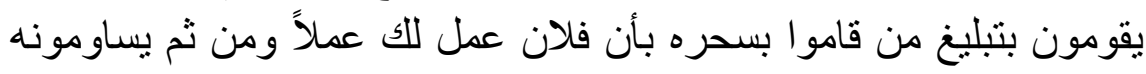

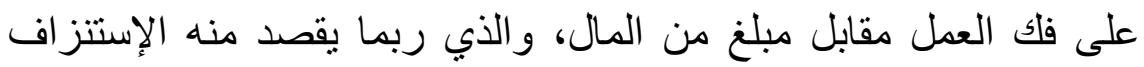

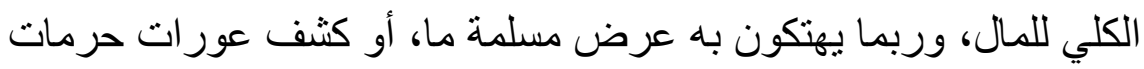

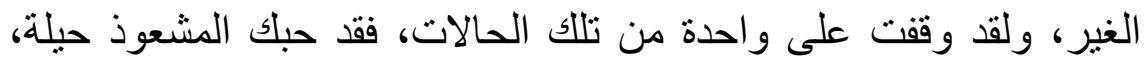

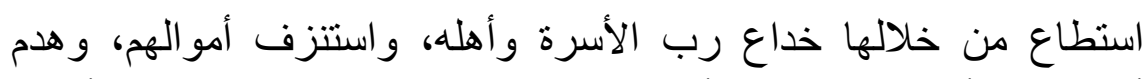

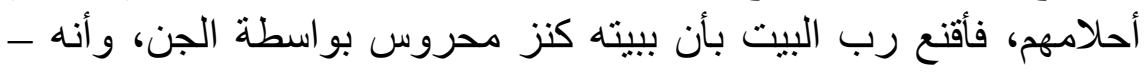

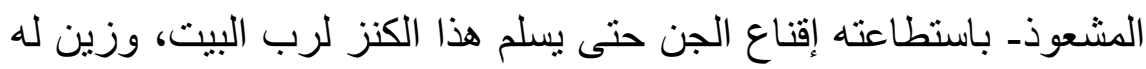

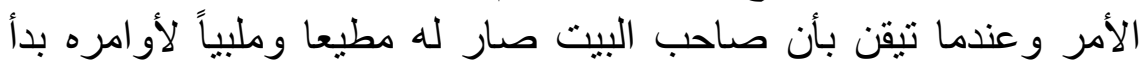

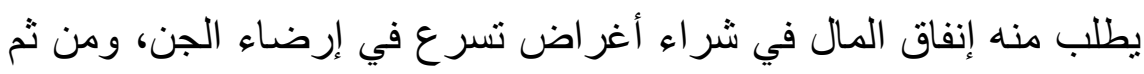

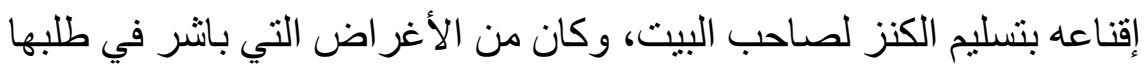

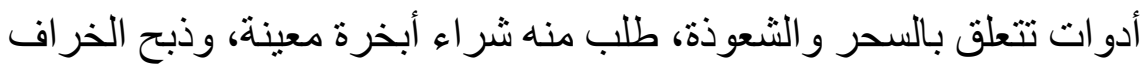

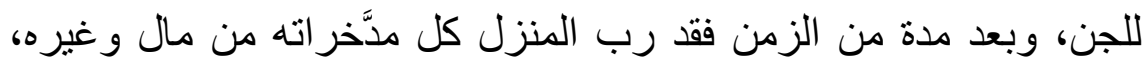

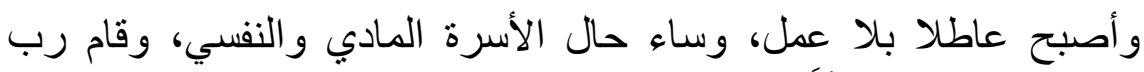

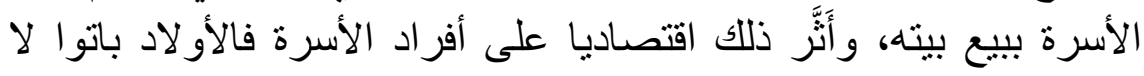

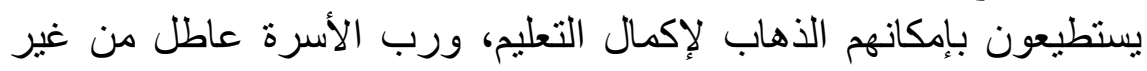

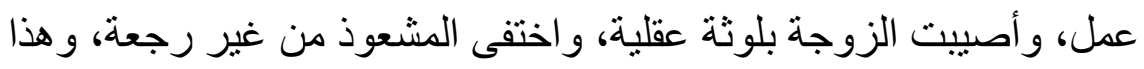

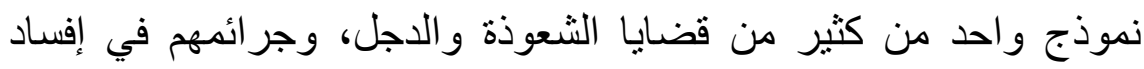

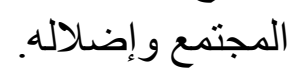
إضعاف العقيدة و الاستقامة

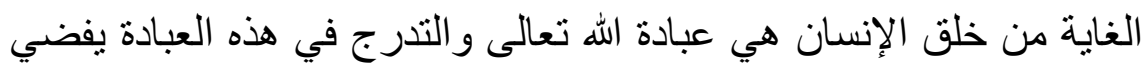

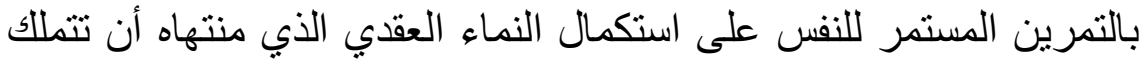

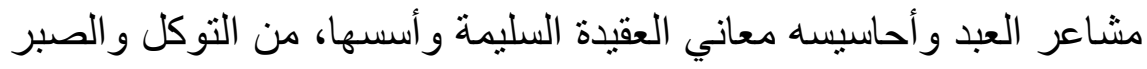

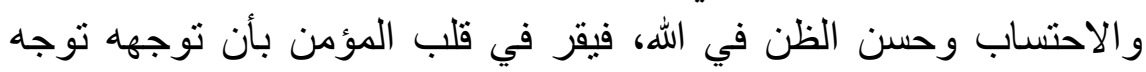

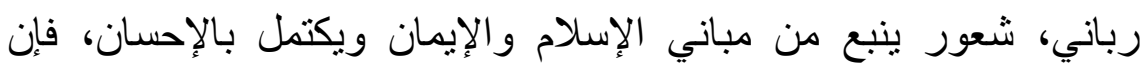

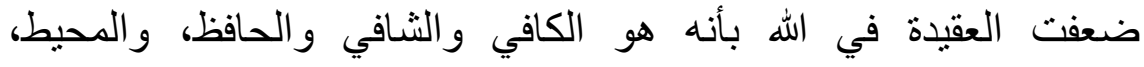
و المهيمن، والقاهر فوق عباده، وهو قاهر أفعال الثر والثر والثياطين والستر

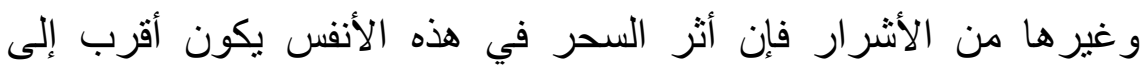


أصحابها، لأنها نفوس تائهة وهائمة وحالمة بسراب القيع، الذي يحسبه

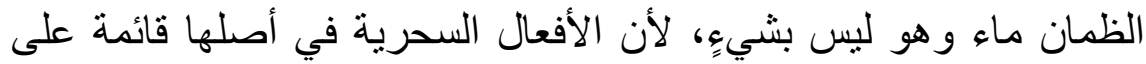

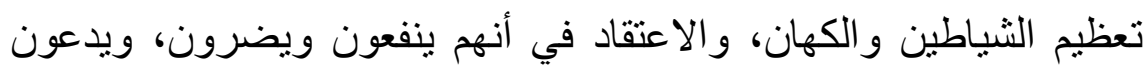

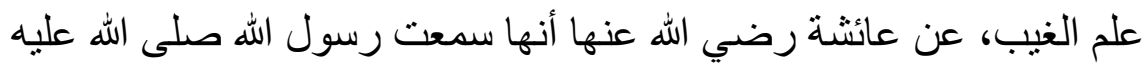

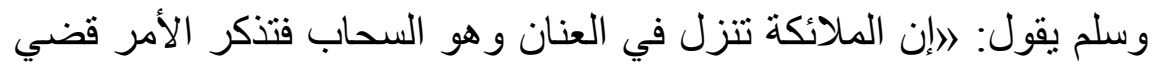
في السماء فتسترق الثياطين السمع فتسمعه فتوحيه إلى الكى الكهان فيكذبون

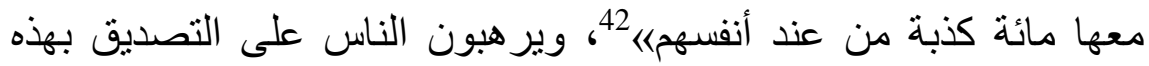

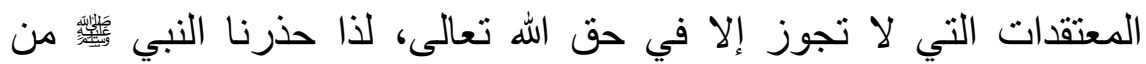

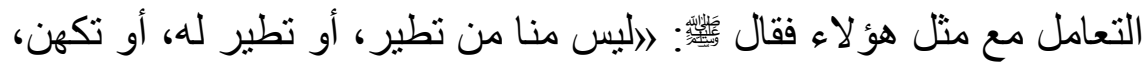

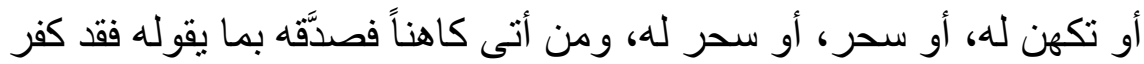

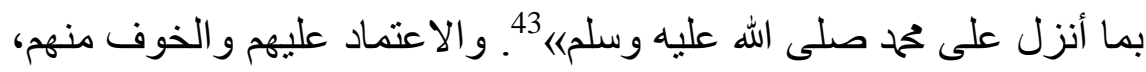

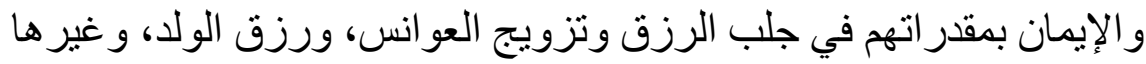

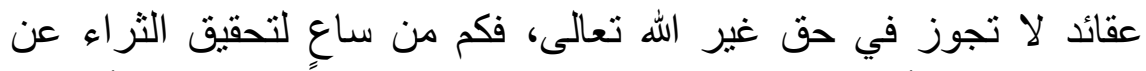

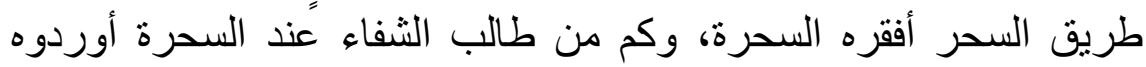

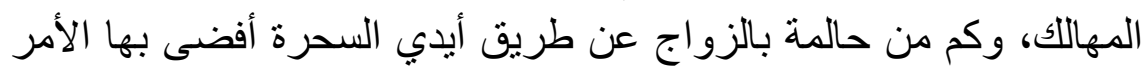

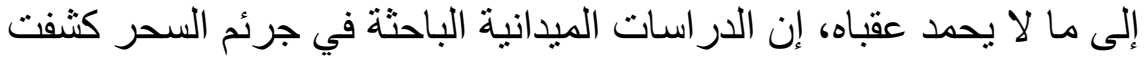

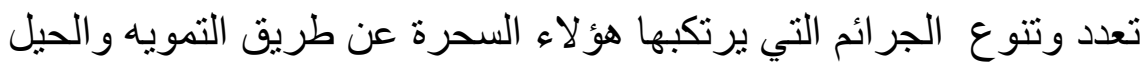
و الخداع، مستقلين حاجة وجهل المجتمع بماهية السحر و أفعال السحرة. تعظيم الشيطان

لقد حذر الله تعالى من التعامل مع الثيطان وأمر بمخالفته لأنه يأمر بالسوء

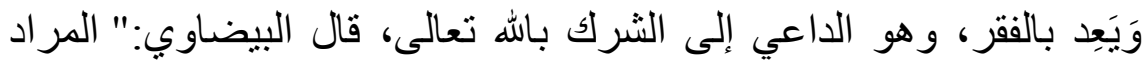

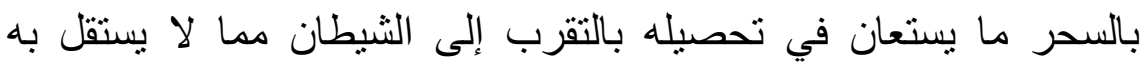

\footnotetext{
42 البخاري، محمد بن إسماعيل، الجامع الصحيح المختصر، تحقيق: د. مصطفى ديب البغا

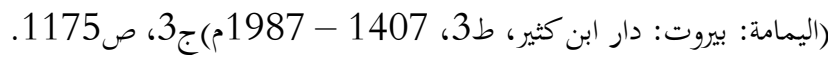

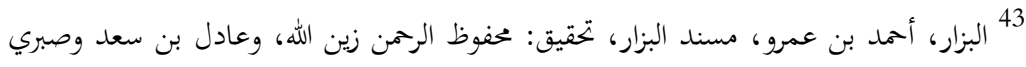

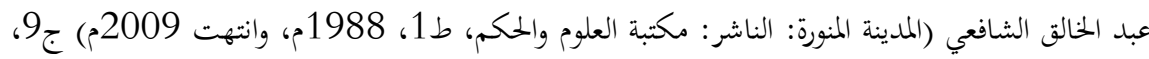


110 Raulsyan Fikr, Vol. 17 No. 1 Januari 2021: 91 - 117.

الإنسان، وذلك لا يستَّبَّ إلا لمن يناسبه في الثرارة وخبث النفس"44، قال

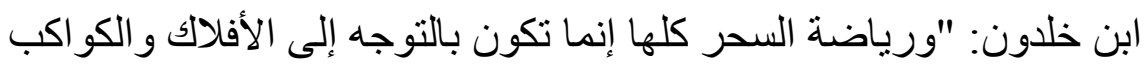

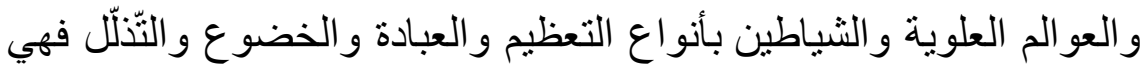

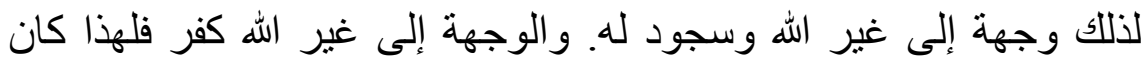

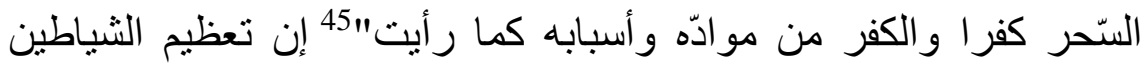

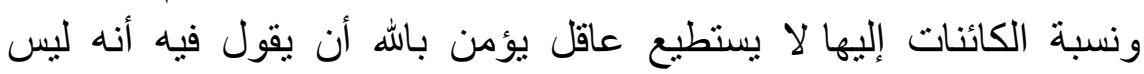

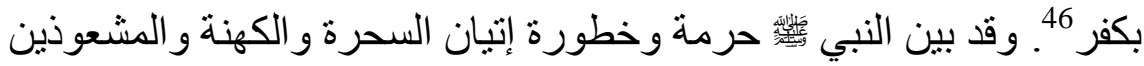

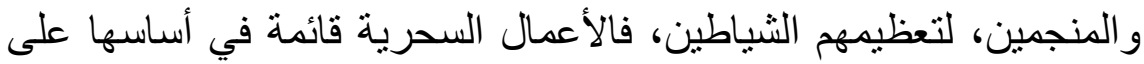

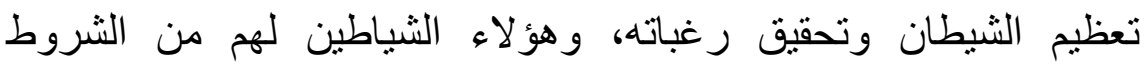

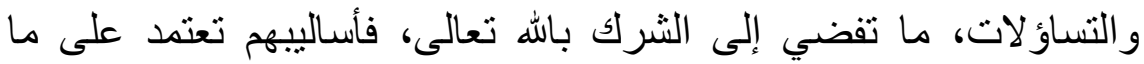

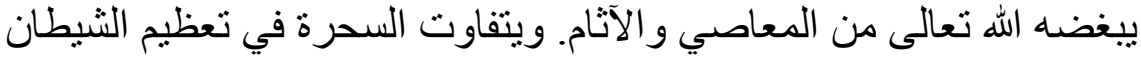
وفق المصلحة المرجوة في نظرهم، فتستعمل الثياطين في جميع الأسحار

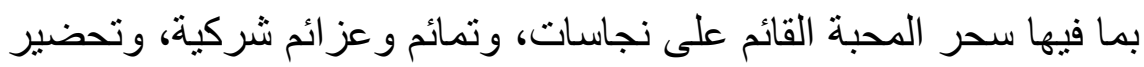

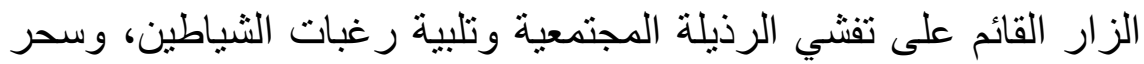

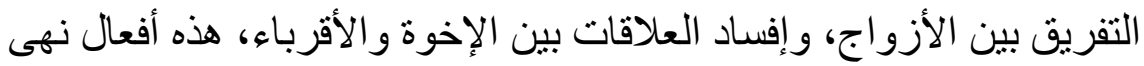

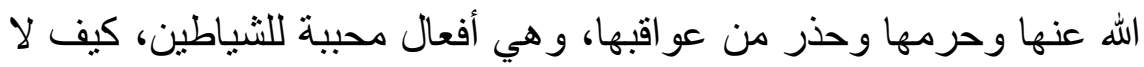

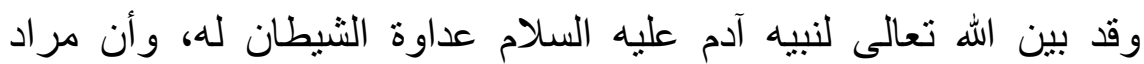

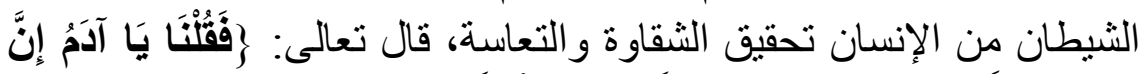

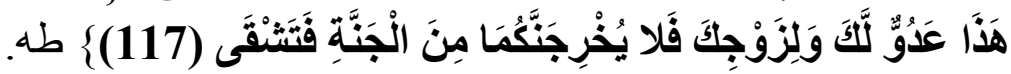

44 البيضاوي، ناصر الدين أبو سعيد عبد الله بن عمر، أنوار التنزيل وأسرار التأويل، تحقيق:

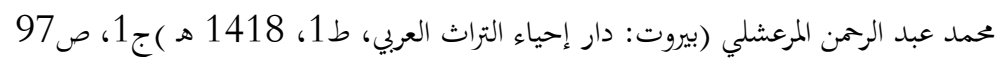

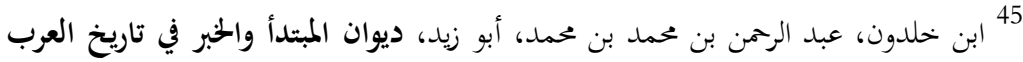
والبربر ومن عاصرهم من ذوي الشأن الأكبر، تحقيق: خليل شحادة (بيروت: دار الفكر، بيروت، ط2 إن،

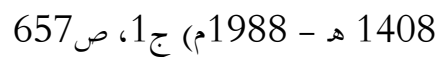
46 محمد بن أحمد بن عرفة الدسوقي المالكي، حاشية الدسوقي على الشرح الكبير (بيروت: دار

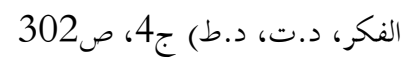




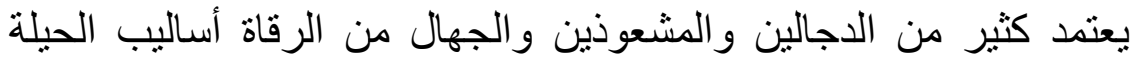

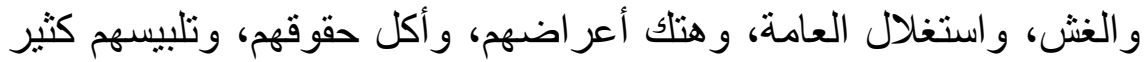

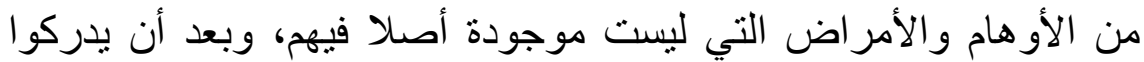

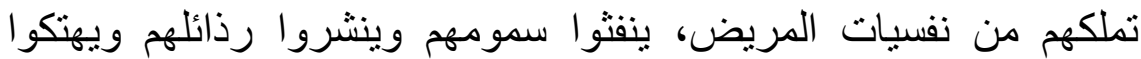

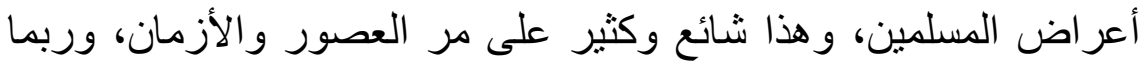

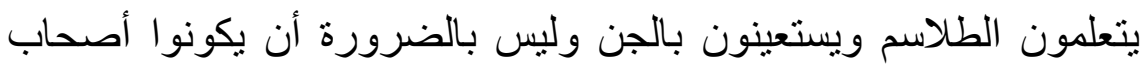

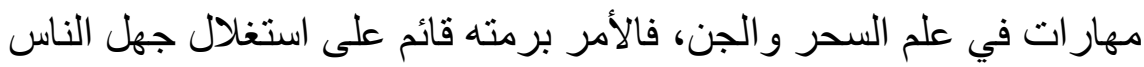

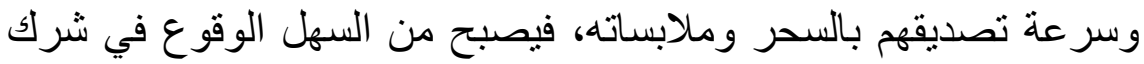

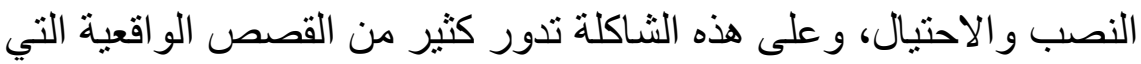

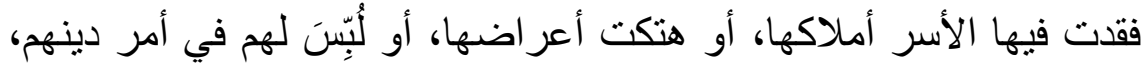

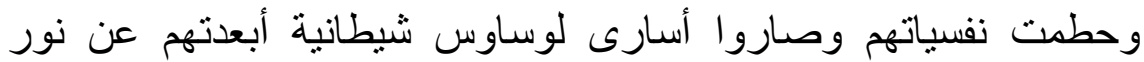

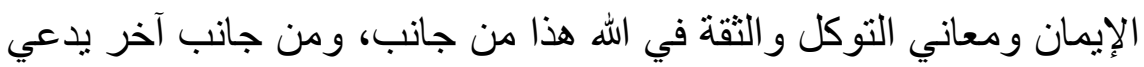

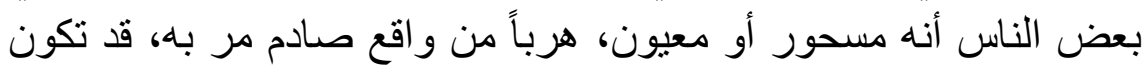

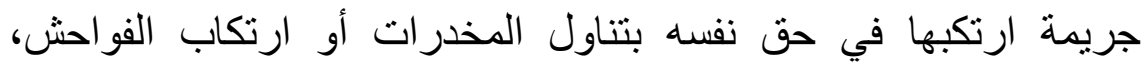

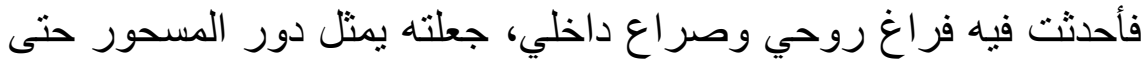

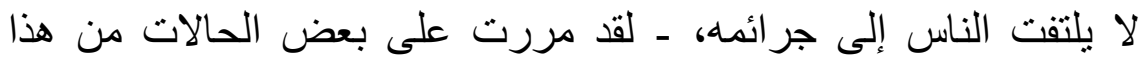

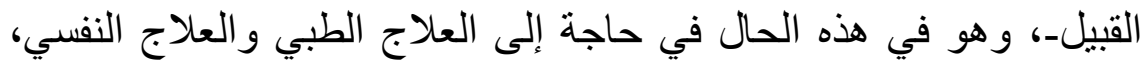
ولن يفيده اللجوء إلى السحرة والدجالين غير جني السراب البي المتوله في في

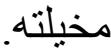

الرعب والتخويف الريف

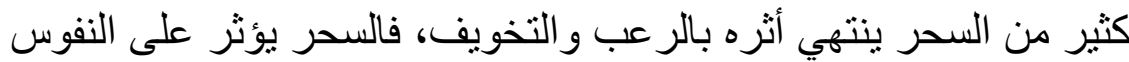

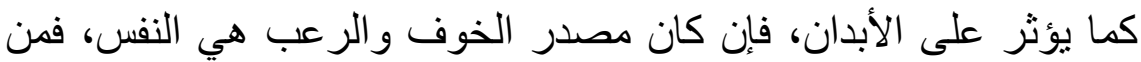

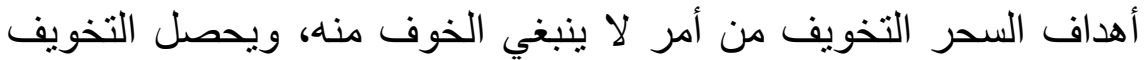

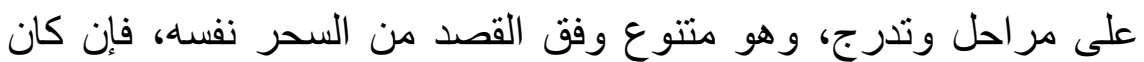

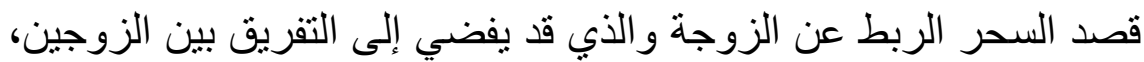

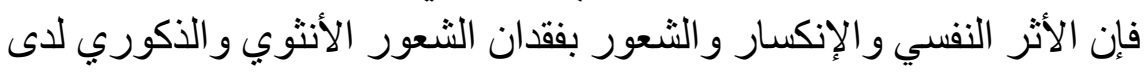

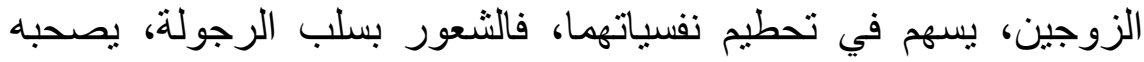

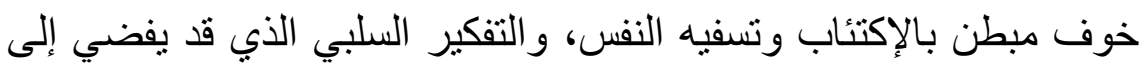


112 Rausyan Fikr, Vol. 17 No. 1 Januari 2021: 91 - 117.

أبعد من ذللك، وفي هذا الأمر يشترك التوهيم و السحر، فكلاهما قد يشعرا

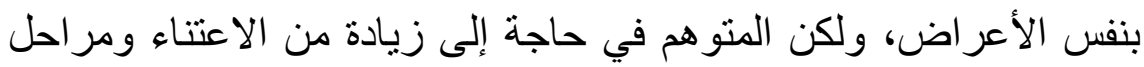
عديدة ليتجاوز تلك المحنة، و هو في حاجة إلى جلسات اسنشارية أكثر منها كقراءة، وعلى ذلك فقس أحوال الراغبين و الراغبات في الزواج وتحقيق هوته

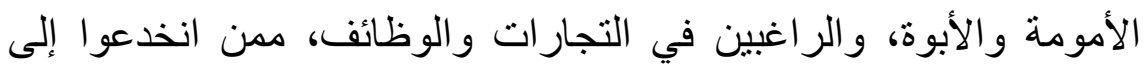

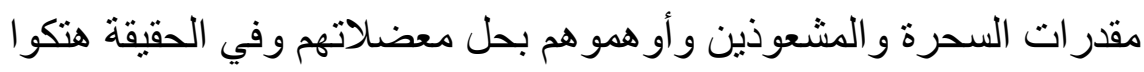

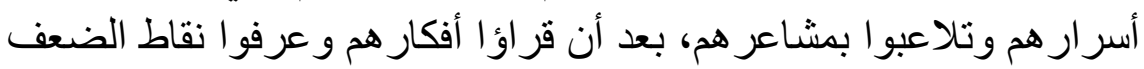
في شخوصهم، فكم من عذراء وققت بأبواب المشعوذين طالبة تسهيل الزواج، وكم من عقيم هرولت سرا من غير علم زوجها طلبا في ربطه أو واء الإنجاب، وكم من عاطل عن العمل صنار ألعوبة في أيدي السحرة

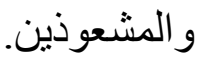

الخاتمة

1- تعد ظاهرة السحر وملازماته من الثعوذة و العين و المس، و الأوهام، حالة مجتمعية شاملة، ومسببة لكثير من أمراض النفس من اكتئاب، و هستيريا،

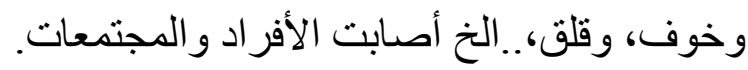

2- يغلب على الأفعال السحرية، تضليل الناس و أكل أمو الهم بالباطل، وتعظيم الثيطان، ومعصية الرحمن، ونشر الحيل و الغش والخداع، وساهمت في تعطيل موارد الأفر اد و المجتمعات، اقتصاديا، واجتماعياً. 3- بين السحر و الو هم و الحيلة و الخداع و الثعوذة روابط نلتقي فيها، وفو اصل

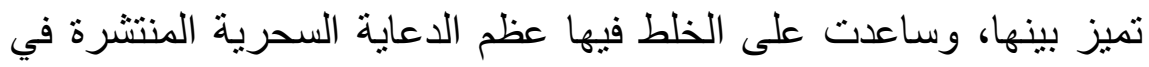
المجتمع. 4- يمكننا تقسيم أنواع السحر بالنظر في تتوع تصنيفاته عند العلماء إلى ثلاثنة

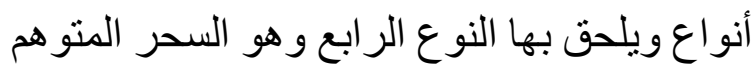

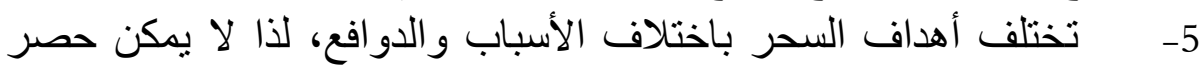
أهداف السحر في نقاط محددة، ولكن بمكننا إجمالا التركيز على أبرز

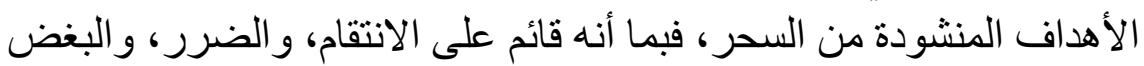
و الحسد، و التنافس الدنيوي بين أفر اد المجتمع، فتتعدد أهدافه وتتباين. 
Shayuthi, Ismail, Ahmed, .... ظاهرة السحر والثعوذة مدارسة

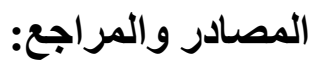

د.أحمد المجتبى بانقا، الجامعة الإسلامية العالمية ــماليزيا، أثر السحر في الإضطرابات النفية قراعة في ثناينا الحديث النبوي، الإية مجلة مركز

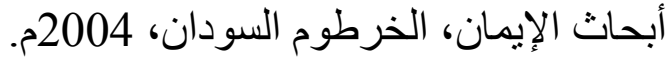

أحمد بن علي أبو بكر الرازي الجصاص، أحكام القرآن، تحقيق: عبد السلام

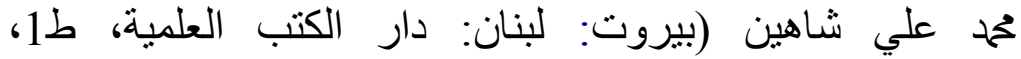
1415 هـ/1994م).

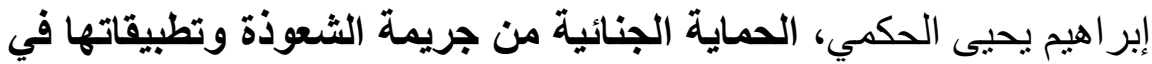

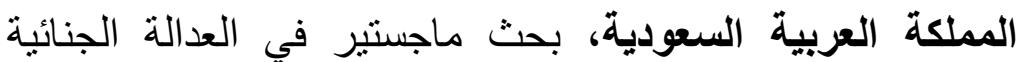
تخصص التشريع الجنايئ الإسلامي، جامعة نايف العربية للعوم

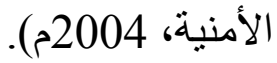

ابن الأثثر، المبارك بن محمد الجزري، النهاية في غريب الحديث والأثر، تحقيق: طاهر أحمد الزاوى- محمود محم الطناحي (بيروت: المئي المكتبة

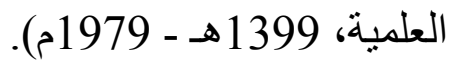

إسماعيل بن حماد الجوهري، الصحاح تاج اللغة وصحاح العربية، تحقيق: أحمد عبد الغفور عطار (بيروت: دار العلم للملايين، ط4، 1407هـ

$$
\text { (م) 1987 - }
$$

البخاري، ححمد بن إسماعيل أبو عبد الله: الجامع الصحيح، تحقيق مصطفى دائى

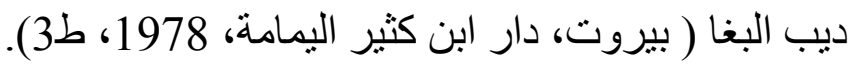

البزار، أحمد بن عمرو، مسند البزار، تحقيق: محفوظ الرحمن زين الله، و عادل بن سعد وصبري عبد الخالق الثافعي (المدينة المنورة: الناشر : مكتبة العلوم و الحكم، ط1، 1988م، وانتهت 2009م). البوني أبو العباس أحمد بن علي: شمس المعارف الكبرى ( لبنان: بيروت:

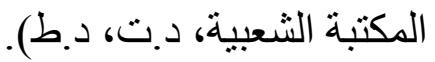


114 Rausyan Fikr, Vol. 17 No. 1 Januari 2021: 91 - 117.

البيضاوي، ناصر الدين أبو سعيد عبد الله بن عمر، أنوار التنزيل وأسرار التأويل، تحقيق: عحمد عبد الرحمن المرعثلي التيد (بيروت: دار إحياء

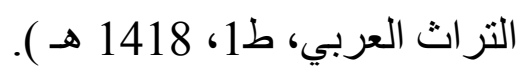

الترمذي، ححمد بن عيسى بن سَوْرة، سنن الترمذي، تحقيق وتعليق: أحمد ححمد

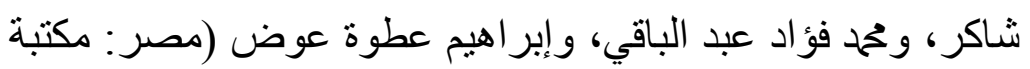

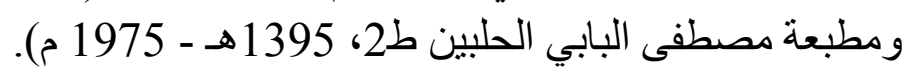
حاجي خلفية، مصطفى بن عبد الله، كشف الظنون في أسماء الكتب والقنون (بغداد: مكتبة المثنى، مطن عبد، 1941م).

ابن حجر، أحمد بن علي بن حجر العسقلاني، فتح الباري شرح صحيح

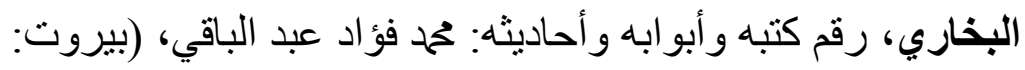

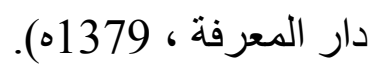

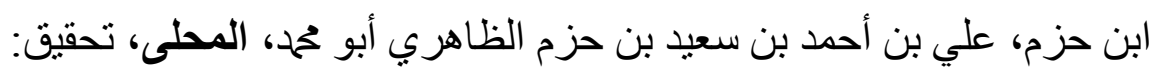

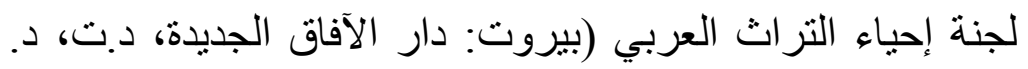
(b حسين بن عبد الرحمن، الإثبات في جريمة السحر في بين الثريعة والقانون،

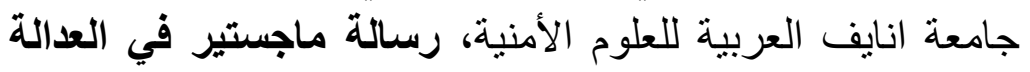

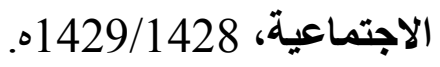

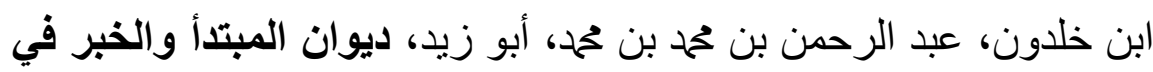

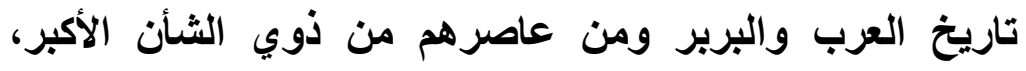

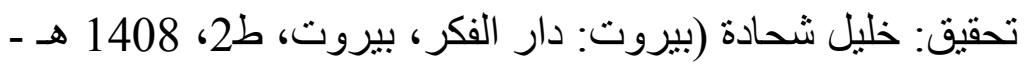

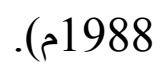

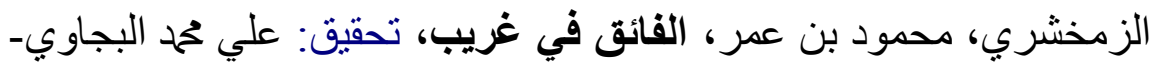
محمد أبو الفضل إبراهيم (لبنان: دار المعرفة، ط2، دئ د.ت).

د. سعيد، الحسين عبدولي، مايكرو سيكولوجيا الجريمة من خلات الدئل

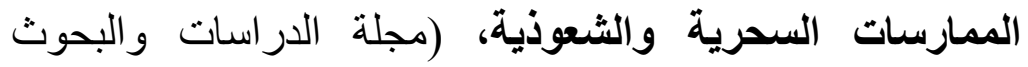
الاجتماعية، جامعة الو ادي، العدد الخامس الهمردية ولة، 2014م). 
Shayuthi, Ismail, Ahmed, .... ظاهرة السحر والثعوذة مدارسة

السبكي، تاج الدين عبد الوهاب بن تقي الدين، طبقات الثافعية الكبرى،

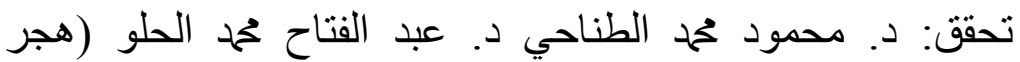

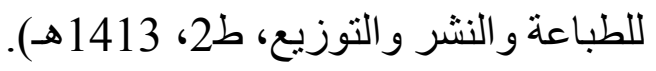

الشوكاني، ححمد بن علي بن ححم بن عبد الله الثوكاني، فتح القدير (دمشق:

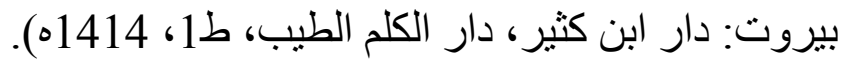

الطبراني، سليمان بن أحمد بن أيوب بن مطير، المعجم الكبير، تحقيق:

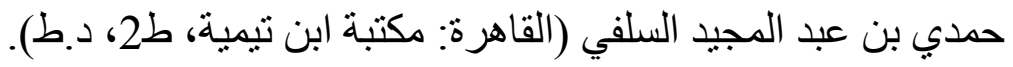

ابن عاثور، الثيخ محمد الطاهر ، التحرير والتنوير (تونس: دار سحنون للنشر

$$
\text { و التوزيع، 1997م). }
$$

ابن عاثور، تحمد الطاهر التونسي، التحرير والتتوير المعروف بتفسير ابن

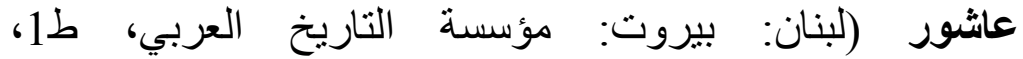

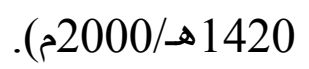

د عواد بن عبد الله المعتق، حقيقة السحر وحكمه في الكتاب والسنة

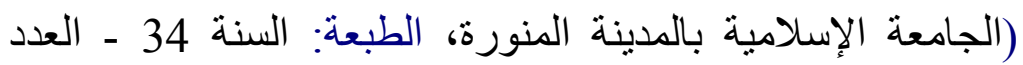

$$
\text { 2002/202 } 11522 \text { - } 142
$$

أ. د. عبد الله بن ححمد بن أحمد الطيار، كيف تتخلص من السحر (دار المتعلم:

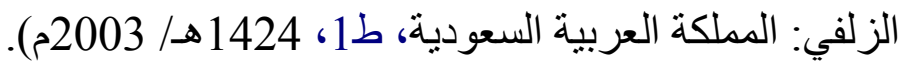

ابن قتيبة، أبو ححم عبد الله بن مسلم: تأويل مختلف الحديث، تحقيق محمد زهري النجار (بيروت، دار الجيل ، 1972).

ابن قدامة، عبد الله بن أحمد المقدس، المغتي في فقه الإمام أحمد بن حنبل الشيباني (بيروت: دار الفكر، ط1، 1405).

القنوجي، صديق بن حسن: أبجد العلوم، تحقيق عبد الجبار زكار (بيروت،

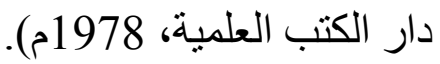

القرطبي، ححمد بن أحمد بن أبي بكر بن فرح، الجامع لأحكام القرآن، تحقيق:

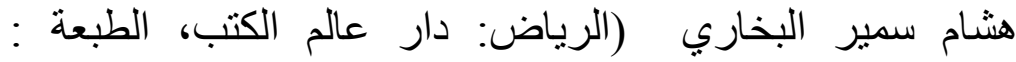

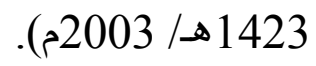


116 Rausyan Fikr, Vol. 17 No. 1 Januari 2021: 91 - 117.

القرافي، أبو العباس أحمد بن إدريس الصنهاجي، الفروق أو أنوار البروق

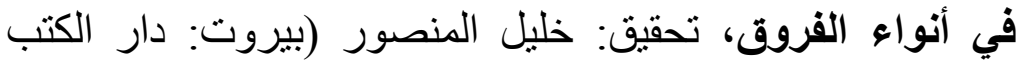

$$
\text { العلمية، 1418 14هـ - 1998م). }
$$

القنوجي، صديق بن حسن، أبجد العلوم، تحقيق: عبد الجبار زكار (بيروت:

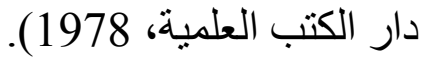

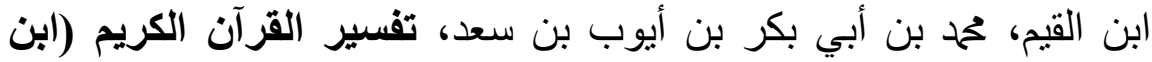

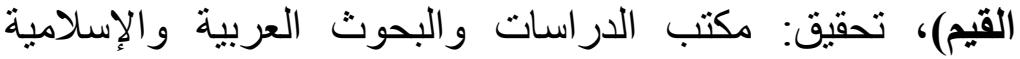
بإنشر اف الثيخ إبر اهيم رمضان (بيروت: دار ومكتبة الهلال، ط1ا، (1410 هـ 140

ابن القيم، محمد بن أبي بكر أيوب، بدائع الفوائد، تحقيق: هثام عبد العزيز

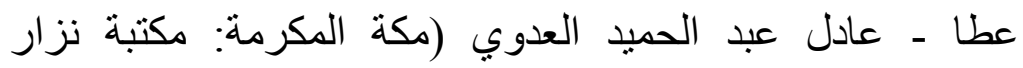

$$
\text { مصطفى الباز ، ط1، } 1416 \text { - 1996). }
$$

ابن القيم، محمد بن أبي بكر بن أيوب بن سعد، الطب النبوي، تحقيق: السيد

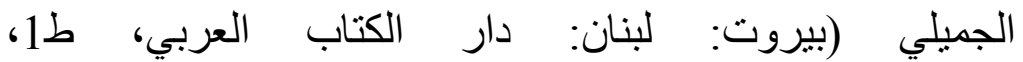

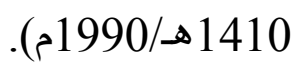

الماوردي، أبو الحسن علي بن محا، الحاوي في فقه الثدافعي (بيروت: دار

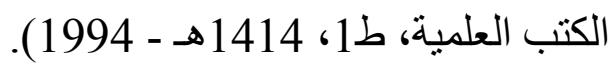

محمد بن أحمد بن عرفة الدوقي المالكي، حاثية الاسوقي على الثرح الكبير

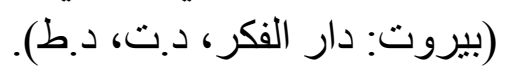

مسلم بن الحجاج النيسابوري، صحيح مسلم، تحقيق: محمد فؤاد عبد الديد

$$
\text { الباقي (بيروت: دار إحياء التراث العربي، د.ت، د.ط). }
$$

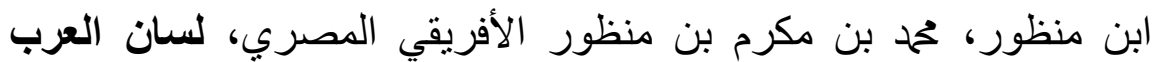

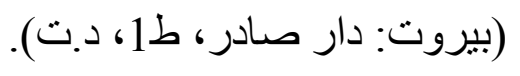

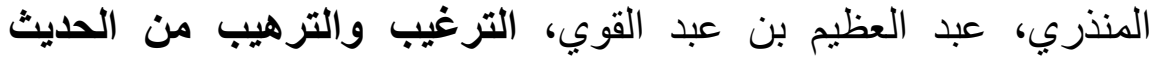
الثريف، تحقيق: إبراهيم شمس الدين (بيروت: دار الكتب العلمية،

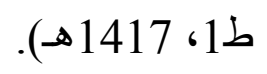


Shayuthi, Ismail, Ahmed, ... | 117

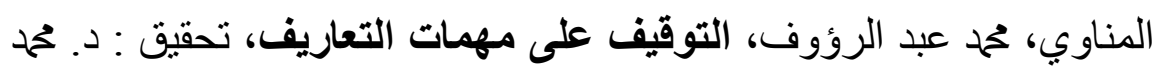

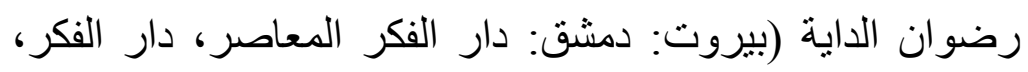

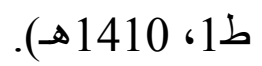

